\title{
The Predictive Ability of a Risk-Adjusted Yield Spread for Economic Activity in Europe
}

by

\author{
Alfred V Guender \\ Bernard Tolan* \\ University of Canterbury \\ New Zealand Treasury \\ Christchurch, New Zealand \\ Wellington, New Zealand \\ \& Freie Universität Berlin, Germany
}

\section{JEL Codes: E3, E4, G1}

Key Words: corporate bond yield spread, predictive content, economic activity in Europe, Financial and Debt Crisis.

\begin{abstract}
This paper examines whether the pricing of risk is important for macroeconomic activity at the country level. We design a risk-adjusted yield spread and test its predictive content for economic activity on the periphery and the centre of Europe over the 1990-2012 period. This risk-adjusted bond yield spread is defined in a cross-country context and referred to as the GZ-type spread. Increases in the yield on corporate bonds issued in the countries on the periphery relative to the riskless yield (calculated using German zero-coupon term structure data) reflect increases in the risk premium that the financial market imposes on borrowers. The risk premium rises in all countries during European-wide recessions of the recent past, particularly those associated with the Global Financial and the Sovereign Debt Crisis. Our findings indicate further that this GZ-type spread acts as a reliable signal for imminent and near-term economic activity in countries where financial markets were shaken to their foundations during the Crisis period. For Germany, the GZ-spread has predictive content for industrial production but not for the unemployment rate. For GDP its predictive ability is confined to the EMU period.
\end{abstract}

Corresponding Author: Alfred V Guender (Alfred.Guender@canterbury.ac.nz), Dept. of Economics and Finance, University of Canterbury, Private Bag 4800, Christchurch, NZ. Phone: 64-3-364-2519. 
The recent twin financial crises have turned the spotlight on asset prices and the sources of corporate borrowing in Europe. Since 2007 the financial press has observed and regularly commented upon two trends that are slowly changing the traditional financial landscape of Europe. First, private-sector companies are increasingly turning towards the bond market to raise financial capital, especially during times of financial strain. The move towards bond financing may only be temporary though since traditionally European firms have relied predominantly on bank loans as a source of finance. ${ }^{1}$ Only a few years ago, in the first quarter of 2007, the volume of bank loans exceeded bond issuance fivefold. Two years later, in the midst of the Global Financial Crisis, bonds began to dominate bank loans as a source of corporate funding. But bank loans did recover their premier status as the effects of the crisis receded. In the first quarter of 2012 European firms again tapped more into the bond market than commercial banks, borrowing US $\$ 179.5$ billion on the bond market compared to $\$ 112.9$ billion from banks. ${ }^{2}$ Second, the financial landscape of Europe is becoming again more fragmented, a sign that the process of financial integration has been disrupted. In the wake of the Global Financial Crisis and the Sovereign Debt Crisis, borrowing costs in the countries on the European periphery have increased dramatically relative to the cost of borrowing in the centre of Europe. Firms in southern European countries and Ireland have faced higher interest rates than firms in Germany because risk premia in the weaker economies on the periphery have surged relative to the centre and because credit conditions have been tighter in the former compared to the latter. In November 2010, companies in Spain, Portugal and Ireland were virtually shut out of the corporate bond market when fear of sovereign default spilled from the sovereign debt market to the corporate debt market. ${ }^{3}$ Bank credit, too, has been squeezed in the periphery countries, partly because of domestic banks' unwillingness and inability to lend, and partly because banks in central and northern Europe have taken steps to cut back their cross-border exposure. ${ }^{4}$ As a direct consequence of the Sovereign Debt Crisis, corporate borrowing rates on bank loans in Spain and Italy have risen much faster than in Germany. Indeed in the third quarter of 2012 they stood at $6.5 \%$ and $6.24 \%$, respectively,

\footnotetext{
${ }^{1}$ Wall Street Journal, “Bonds with Banks Fraying,” April 10, 2012.

${ }^{2}$ Ibid.

${ }^{3}$ Financial Times, "European Company Borrowing Costs Rise," November 30, 2010. The article reports that "the last bond issue from a company domiciled in Spain, Portugal or Ireland came from Iberdrola, the Spanish utility, on October $6^{\text {th }}$." Thus no corporate bond placement was effected in almost two months.

${ }^{4}$ Financial Times, "Loan Rates Point to Eurozone Fractures," September 3, 2012. The rates quoted are the average rate on loans to non-financial corporations, 1-5 years, up to $€ 1$ million in value.
} 
their highest level in both countries since late 2008 while in Germany the rate was just 4.04 $\%$ and thus only slightly above its minimum since late $2008 .^{5}$

This paper examines whether information from bond markets provides a reliable signal for future economic activity in Europe. It evaluates the marginal predictive content and economic significance of a risk-adjusted credit spread in five European countries from the early 1990s to the recent past. Following the lead of the financial press, we distinguish between the periphery and the centre of Europe. Four countries - Ireland, Italy, Portugal, and Spain - are members of the European periphery while Germany represents the centre of Europe. ${ }^{6}$ The credit spread is defined as the average of yields on outstanding corporate bonds in a country on the European periphery less a riskless yield. The riskless yield is computed using data from the zero-coupon curve of German government bonds (Bunds). German Bunds are thus deemed to be safe havens.

The theoretical underpinnings for the ability of a credit spread to predict future activity are deeply rooted in the credit view of the transmission process of monetary policy. Central to the credit view is that an exogenous event such as a tightening of monetary policy or a shock to financial markets has flow-on effects that go beyond mere changes in short-term interest rates. Such a shock lowers the net worth of firms (households) dependent on access to credit to finance investment (consumption) spending. The balance sheet is impaired primarily because the value of collateral and cash flow decline, thus raising the cost of external finance at the margin. More important, the gap between the external and internal cost of finance widens because the firm is now perceived to be riskier. A widening gap signals that the borrower's ability to finance planned investment or consumption expenditure is constrained. ${ }^{7}$ A similar rationale lies behind the credit spread employed in this paper. In times of financial stress, credit conditions tighten. The supply of credit decreases because the creditworthiness of firms deteriorates. The risk premium on privately issued bonds rises, leading to a widening in the spread between risky private bond yields and the riskless yield. Worsening credit conditions in turn reduce spending and consequently real economic activity declines. This view of the credit channel of the monetary transmission mechanism takes sovereign default risk as non-existent. In the countries on the European periphery this assumption was clearly

\footnotetext{
${ }^{5}$ Ibid.

${ }^{6}$ Ideally, we would have included Greece in our examination. Unfortunately, data constraints made this impossible. Germany is chosen to be the centre on account of it having the largest economy in Europe and its triple A credit rating.

${ }^{7}$ This is the gist of the Financial Accelerator effect (Bernanke and Gilchrist (1996), Bernanke, Gertler, and Gilchrist (1999)). For a non-technical analysis, see Bernanke and Gertler (1995) or Hubbard (1995).
} 
not tenable after 2010. In fact the deterioration in governments' perceived creditworthiness had adverse consequences for the entire domestic financial sector in these countries. The spectre of sovereign default risk caused a great deal of uncertainty - private bond issuance dropped significantly - and led to substantial increases in risk premia on privately issued bonds. The banking sector could not be relied on to absorb the funding needs of firms. In the countries on the periphery, banks faced serious funding challenges themselves as they were also perceived to be riskier as a result of their exposure to sovereign debt. ${ }^{8}$ Banks' cost of raising deposits and wholesale debt rose dramatically as did the bank lending rates in the weak Euro area countries. These developments led to the emergence of massive spreads between yields in countries of the periphery and the core.

The focus of the present analysis rests on a yield spread which we call the GZ-spread (because it follows the "bottom-up" approach proposed by Gilchrist and Zakrašjek (2012)). The inclusion of the bond yield spread improves markedly the goodness of fit of the forecasting equation for economic activity in countries on the European periphery. ${ }^{9}$ The within-sample forecasting ability of the GZ-spread is remarkable, both over the whole sample period and a sub-sample period marking the effective beginning of the Economic and Monetary Union of Europe (EMU) in 1999. Indeed since the establishment of the EMU its economic significance in predicting future economic activity has increased in most countries on the European periphery that have been hit hard by the recent turmoil in financial markets. The marginal predictive content of the GZ-spread for changes in economic activity in these countries is impressive even after accounting for the effect of standard monetary policy measures such as the slope of the term spread and a short-term money market rate.

\footnotetext{
${ }^{8}$ On this see Committee on the Global Financial System, CGFS Papers, No 43, 2011. This report covers events only up to 2010. Neri and Ropele (2014) investigate the link between tensions in sovereign debt markets and credit conditions in the Euro area, particularly the banking sector of individual countries during the Sovereign Debt Crisis.

${ }^{9}$ There has been a long-standing interest in the predictive ability of various financial indicators for economic activity and inflation. Among the most frequently used proxies for monetary conditions are the yield spread on long-term and short-term government bonds (Bernanke (1988), Harvey (1988), Estrella and Hardouvelis (1991), and others) and the risk spread, defined as the difference between the yield on short-term commercial paper and the yield on Treasury Bills of the same maturity (Friedman and Kuttner (1992), (1998), Emery (1996)). Moersch (1996) finds that money market spreads predict output better than other spreads along the yield curve. Various US bond yield spreads (long-term, high yield) figure prominently in Gertler and Lown (1999), Mody and Taylor (2004) and King et al (2007). De Bondt (2004) analyses bond yield spreads in Europe. More recent contributions such as Mueller (2009) also examine corporate bond yield spreads defined along rating categories in the context of a macro-finance term structure model of the type proposed by Ang, Piazzesi, and Wei (2006). A comprehensive survey of the literature on the role of asset prices in forecasting economic activity is by Stock and Watson (2003).
} 
Like Gilchrist and Zakrašjek (2012), we also examine the predictive content of a countryspecific GZ-spread. The GZ-spread constructed for Germany consists of the difference between the yields on German corporate bonds and the riskless German Bund yield. ${ }^{10}$ The predictive ability of the "internal" GZ-spread for economic activity in Germany is spotty. The GZ-spread matters for the growth rate of industrial production and real GDP over some horizons but appears to have no bearing on future changes in the rate of unemployment.

In one important respect the objective of the current examination of bond yield spreads in Europe is more modest than Gilchrist and Zakrašjek's (2012) study of US corporate bond yield spreads. The GZ-spread employed in the current paper does not distinguish between a systematic part - the portion of the risk premium attributable to firm-specific factors - and the unsystematic part - the excess bond premium - that bond holders demand over and above compensation for expected default loss. ${ }^{11}$

In the next section, we explain in greater detail the calculation of the GZ-type spread that is used in the forecasting equation. Section 3 presents summary statistics of the data and the GZ-spread. The specification of the forecasting equation is explained in detail in Section 4. The predictive content of the GZ-spread and standard measures of monetary policy for economic activity is examined in Section 5. Section 6 offers a brief conclusion.

\section{Calculation of the GZ-Spread}

Except for the German GZ-spread, our method of constructing the GZ-spread is somewhat different from the one proposed by Gilchrist and Zakrašjek (2012). Our method uses rates from the German zero curve as reference rates to calculate the price of a riskless bond in a country on the European periphery. This synthetic bond has the same coupon schedule as a given corporate bond issued in a country on the European periphery. Unlike Gilchrist and Zakrašjek, we exclude bonds with embedded options.

The procedure we follow to calculate the GZ-spread comprises two parts. First, we calculate the monthly spread between the yield on corporate bond $j$ in country $a$ and the risk-free

\footnotetext{
${ }^{10}$ Bleaney, Mizen, and Veleanu (2012) compose country-specific GZ-spreads in the spirit of Gilchrist and Zakrašjek (2012) for a number of European countries. Their analysis of the predictive content of credit spreads differs from ours in three important respects. They are: construction of the GZ-spread, countries included in the study, and estimation method. According to the findings of their panel data study, the GZ-spread is a reliable predictor of future economic activity in Europe.

${ }^{11}$ The extraction of the excess bond premium requires firm-specific data which the authors do not have. It would no doubt be interesting to ascertain whether, as in Gilchrist and Zakrašjek (2012), the excess bond premium accounts for most of the forecasting success of the GZ-spread.
} 
German yield at time $t$. Second, we calculate the GZ-spread at the country level by averaging the individual bond spreads in country $a$ in a given month. This procedure is set out in detail below.

We first obtain monthly yield-to-redemption data on senior, unsecured corporate bonds from DataStream for every country in our sample (Portugal, Ireland, Italy, Spain and Germany). Our sample period begins in 1990 shortly after German reunification, and spans the transition to the Economic and Monetary Union and the Global Financial Crisis before finishing in 2012 in the midst of the Sovereign Debt Crisis. Like Gilchrist and Zakrašjek, we include bonds of only non-financial firms.

Next, we obtain the risk-free rate which we use to create the GZ spread at the 'bond level'. In order to obtain a risk-free rate without 'duration bias,' we require a German risk-free bond with the same coupon schedule as corporate bond $j$ in month $t$. Of course no such bond exists, so we follow Gilchrist and Zakrašjek and create a 'synthetic risk-free bond'. This synthetic bond, in effect, is a German federal government bond with the same coupon schedule at time $t$ as corporate bond $j$.

To find the yield for the synthetic German security which matches corporate bond $j$ in month $t$, we first need to calculate its price. The price of corporate bond $j$ in a given country at time $t, P_{j t}^{c o r p}$, is calculated by applying the discount function, $D(t)$ to a stream of $s$ regular coupon payments where $C(s): s=1,2 \ldots S, D\left(t_{s}\right)=e^{-r t}$ and ' $r$ ' is the yield to maturity:

$$
P_{j t}^{c o r p}=\sum_{1}^{s} C(s) D\left(t_{s}\right)
$$

The price $P_{j t}^{\text {risk-free }}$ of a synthetic German security at time $t$ can be found by discounting $C(s)$ using $s$ zero coupon risk-free interest rates. That is, $D\left(t_{s}\right)=e^{-r f_{t m} t}$ where $r f_{t m}$ is the German zero rate at time $t$ with a maturity $m$ corresponding to the time until coupon payment $s$.

We obtain $r f_{t m}$ from a German zero curve downloaded from the Bundesbank website. For each month, the zero curve plots German zero securities of ascending maturity (six months up to thirty years in yearly intervals from one year up) on the $\mathrm{x}$-axis and their corresponding yields on the y-axis. Where necessary, we linearly interpolate to get the risk-free discount rate with the exact same maturity as a given coupon payment. 
Once we have the price of the German synthetic bond, we numerically solve for the yield-tomaturity (this is just the internal rate of return). The result, $Y_{j t}^{\text {risk-free }}$ is the risk-free portion of the 'bond-level' spread for bond $j$ at time $t$.

Next, we calculate the risk-free rate for every bond in our sample using the method described above.

We then subtract the risk-free rate from the yield on corporate bond $j$ at time $t$ in country $a$. The result, $S_{j t}^{a}$, is the spread at the 'bond level':

$$
S_{j t}^{a}=Y_{j t}^{\text {corp }}-Y_{j t}^{\text {risk-free }}
$$

The final step is to average the spread in country $a$ at time $t$ to create the GZ-spread $G Z_{t}^{a}$ at the country level:

$$
G Z_{t}^{a}=\frac{1}{n_{t}} \sum_{j} S_{j t}^{a}
$$

$n_{t}=$ the number of bond observations in month $t^{12}$

For example, to find the Italian GZ spread in January 2007, average all of available observations of the Italian bond level spreads in that month. Thus the credit spread is representative of the entire maturity and credit quality spectrum as emphasized by Gilchrist and Zakrašjek (2012). We also follow their example of eliminating from the sample bonds with remaining terms of maturity of less than one year or more than 30 years. In the same vein, extreme observations of the GZ-spread, i.e. those below 0.05 percent or above 35 percent were scrapped from the sample.

\section{The GZ-Spread in the Centre and on the Periphery of Europe: Basic Facts}

Table 1A provides summary statistics of the data used in the empirical analysis. The number of bond-issuing firms varies from a low of 13 for Ireland and Portugal to a high of 62 for Germany. The number of corporate bonds issued during the sample period, which is countryspecific, ranges from a low of 42 for Portugal to a high 330 for Germany. Despite its limitations in terms of size, the sample of the corporate bonds is taken to be representative of

\footnotetext{
${ }^{12}$ Since this spread is calculated in a cross-country context, the measured spread consists of a combination of two components. One measures corporate credit risk while the other reflects peripheral country risk.
} 
conditions in the market for corporate debt at the country level. ${ }^{13}$ The mean yield is highest in Ireland and lowest in Germany. The mean maturity at issue of bonds is far longer in Spain (11.81 yrs.) and Ireland (12.76 yrs.) than in Germany where it is slightly below seven years. ${ }^{14}$ Summary statistics of the GZ-spread for Germany, Ireland, Italy, Portugal, and Spain appear in Table 1B. Data limitations for Spain and Portugal restrict a cross-country comparison of the summary statistics over the 1990-2012 sample period to Italy, Ireland, and Germany. The GZ-spread can be calculated for Spain only from 1996 onward; for Portugal the GZ-spread starts even later, in April 1999.

Inspection of Table 1B.1 reveals that the GZ-spread is considerably lower and less variable in Germany compared to Italy and Ireland over the whole sample period. Comparing Tables 1B.2 and 1B.3, we observe that the period since the start of the Economic and Monetary Union in 1999 has seen a lower and more stable GZ-spread in Italy and Ireland. ${ }^{15}$ Since 1999 , the volatility of the GZ-spread has been reduced by half in Germany while its mean has risen slightly compared to the pre-1999 period. Breaking down the EMU Period into a pre-Crisis (1999:01-2007:07) period and a Crisis period (2007:08-2012:08) shows that during the Crisis period the mean of the GZ-spread rises in all five countries. The rise is most pronounced in Portugal where the GZ-spread surges upward by almost 300 basis points, followed by Ireland, Spain, and Italy while in Germany the GZ-spread ratchets upward by only 80 basis points. Large increases in the variability of the GZ-spread are observed in Portugal and Spain. Even in Germany the standard deviation of the GZ-spread nearly doubles during the Crisis period. Notice though that the GZ-spread peaks during the Crisis period only in Portugal, Spain, and Ireland when all observations over the whole sample period are taken into account. Evidently, during the Crisis period credit conditions worsen by more in the smaller and medium-size economies on the periphery relative to the larger ones.

\section{The GZ-Spread during Recessions}

\footnotetext{
${ }^{13}$ Our study focuses squarely on the bond market and its participants. Access to the bond market is typically restricted to large and fairly well known companies. Smaller and lesser known companies are forced rely on bank loans to finance their working capital needs. As larger firms have greater flexibility in sourcing finance on the open market or from banks than smaller firms, the latter suffer disproportionately more from a tightening of monetary policy or during times of financial turmoil. One could thus plausibly argue that a bond market credit spread is a conservative indicator of general financial market conditions.

${ }^{14}$ The maturity profile of corporate bonds included in the sample corresponds broadly to that reported by the European Central Bank in its February 2012 Bulletin. Over the 1999-2007 period the average maturity of corporate bonds was shortest in Germany at 4.7 years and highest in Ireland at 8.8 years.

${ }^{15}$ Strictly speaking, January 1, 1999 marks the beginning of the third stage of the Economic and Monetary Union. On this date the Euro officially replaced the Ecu as the official currency of the union. For the first three years the Euro served only as a unit of account. Euro coins and banknotes were not introduced until January 1, 2002.
} 
Figures 1 - 5 track the behaviour of the GZ-spread in the five countries over the respective sample period. The individual graphs show clearly that the GZ-spread is at quite elevated levels in Ireland and Italy at the beginning of the 1990s and in Germany from 1992 to the first quarter of $1996 .{ }^{16}$ The spread is also relatively high initially in Spain before it drops off markedly in 1997 . The GZ-spread never rises above 200 basis points and is relatively stable in Portugal before the Crisis period. Most importantly, however, the five graphs show the countercyclical behaviour of the GZ-spread: it tends to rise before recessions begin and surges dramatically during recessions when perceived risk increases. The recessions appear as shaded areas in each figure. The CEPR Business Cycle Committee has identified three European-wide recessions over the 1991-2012 sample period. The beginning and end of each recession are: ${ }^{17}$

1992 Q1 - 1993 Q3 2008 Q1 - 2009 Q2 2011 Q3 - end of sample period.

The Crisis period includes two recessions. As a result there are twin peaks in the GZ-spread during the Crisis period. Notice, however, that there is no clear-cut, systematic evidence across the five countries that the GZ-spread widens more during the Sovereign Debt Crisis than the Global Financial Crisis (or vice versa). It is true that the former crisis causes far greater surges in the GZ-Spread than the latter in Portugal and Spain and a slightly larger spike in Italy but the pattern is just the reverse for Germany and Ireland where larger increases in the GZ-spread are manifest during the Global Financial Crisis compared to the Sovereign Debt Crisis.

\section{The Forecasting Specification}

To assess the predictive ability of the GZ-credit spread, we employ a specification similar but not exactly the same as the one adopted by Gilchrist and Zakrajšek (2012). A significant difference between their specification and ours results from our using a multiple country framework with an alternative definition of the GZ-spread, an interaction term involving the GZ-spread, and the inclusion of cross-country effects of inflation. In other respects the specification of the forecasting equation is the same. The annualized growth rate of the economic indicator at a given forecast horizon, $\nabla^{h} y_{t+h}$, is regressed on the lagged annualized

\footnotetext{
${ }^{16}$ For Germany one also observes a steep increase in the GZ-spread in 1998 around the time of the Russian Default.

${ }^{17}$ The first recession preceded Black Wednesday in September 1992 when the European Exchange Rate Mechanism came under attack. The second recession was triggered off by the Global Financial Crisis while the third came upon the heels of the European Sovereign Debt Crisis.
} 
growth rate of itself, standard measures of monetary policy, the GZ-credit spread, and an inflation differential:

$$
\begin{gathered}
\nabla^{h} y_{t+h}=b_{0}+\sum_{i=1}^{n} b_{i} \nabla y_{t-i}+c_{1} T S_{t}+c_{2} E U_{t}+c_{3} G Z_{t}+c_{4} G Z_{t} * D U M_{t}+c_{5}\left(I N F_{t}^{\text {Home }}-\right. \\
\left.I N F_{t}^{G e r}\right)+\epsilon_{t+h}
\end{gathered}
$$

$\nabla^{h} y_{t+h}=\frac{c}{h+1} \ln \left(\frac{Y_{t+h}}{Y_{t-1}}\right) h=3,6,12$ (forecast horizon, monthly data) $c=1200$ for monthly data $h=1,2,4$ (forecast horizon, quarterly data) $\quad c=400$ for quarterly data

$T S_{t}=$ Term spread defined as the difference between the yield on 10-year government bonds and the yield on 1-year government paper.

$E U_{t}=$ Inflation adjusted short-term interest rate. The real short term interest rate is defined as the 90-day Euribor (or short-term government yield before EMU) less CPI inflation. The annual rate of CPI inflation is calculated as $100 *\left(\ln C P I_{t}-\ln C P I_{t-k}\right)$ where $k$ $=12$ for monthly data and 4 for quarterly data.

$G Z_{t}=$ credit spread as defined in the previous section.

$D U M_{t}=$ Dummy variable. It is defined as:

$$
\begin{array}{ll}
D U M_{t}=1 & \text { for 2007:08 -2012:04 (referred to as the Crisis period) } \\
D U M_{t}=0 & \text { otherwise. }
\end{array}
$$

$I N F_{t}^{\text {Home }}-I N F_{t}^{G e r}=$ Difference between the rate of inflation in home country and Germany.

According to conventional wisdom, a tightening of monetary policy leads to a flattening of the yield curve, a decrease in the term spread, and a subsequent decrease in economic activity. Increases in the short-term real interest rate and future economic activity are inversely related. Increases in the GZ-spread reflect a tightening of credit conditions in financial markets and cause a downturn in economic activity. We are agnostic about the effects of higher relative inflation on future economic activity. On the one hand, higher inflation in the home country relative to Germany is expected to harm the growth prospects of the home country as higher relative inflation imparts a competitive cost disadvantage and increases transaction costs. On the other hand, higher relative inflation in the home country may be a signal that the home country is in an expansionary phase of the business cycle. 


\section{The Predictive Ability of the GZ-Credit Spread}

In this section we employ the forecasting specification described in the previous section to examine the predictive ability of the GZ-spread alongside standard monetary policy indicators. Tables 2 - 7 report the econometric results of our empirical analysis. The findings of the first four tables are based on monthly data. Quarterly results are reported in Tables 6 and 7.

\section{Monthly Economic Indicators}

Tables $2-5$ present statistical evidence on the forecasting ability of the GZ-spread and standard measures of monetary policy for industrial production and the rate of unemployment for the whole sample period and a sub-sample period which marks the effective beginning of the Economic and Monetary Union in 1999. The forecasting horizon is one month, three months, and twelve months, respectively.

According to Table 2, the two standard measures of monetary policy, the term spread and the real short-term interest rate, have predictive power for industrial production in two of the four countries considered over the whole sample period. The term spread has a strong positive effect on industrial production across all three forecasting horizons in Spain and Germany. There is also an inverse relationship between real economic activity and the inflation adjusted short-term rate in Spain and Germany, albeit the respective effect on industrial production through the short-term real interest rate channel is weaker, both economically and statistically, compared to the slope of the yield curve. For Italy and Ireland there is neither econometric evidence of a positive relationship between the term spread and industrial production nor evidence of an inverse relationship between the real rate of interest and industrial production. The inflation differential relative to Germany exercises a sizeable negative effect on industrial production across all three forecasting horizons in Spain and at the 12-month horizon in Ireland. ${ }^{18}$

The marginal predictive effect of the credit spread on industrial production is captured by the coefficients of GZ and GZ*DUM. The coefficient of the latter regressor captures the distinct marginal effect of the GZ-spread during the Crisis period set off by the outbreak of the

\footnotetext{
${ }^{18}$ The estimated coefficient on the relative inflation differential is reported only if it is statistically significant.
} 
Global Financial Crisis in August 2007 and lengthened by the Sovereign Debt Crisis in Europe. Our empirical results suggest that increases in the GZ-spread proper predict lower industrial production only in Ireland across all forecasting horizons prior to the Crisis period. With the onset of the Global Financial Crisis, however, the negative effect of the GZ-spread on industrial production is widely felt in Spain, Italy, and Ireland and Germany at the 12month forecasting horizon as evidenced by the negative and statistically significant coefficient on GZ*DUM. The most compelling evidence for a significant change in the predictive ability of the GZ-spread during the Crisis period is found in Spain where its material effect on economic activity relative to the pre-Crisis period is evident at all forecasting horizons. Indeed, the marginal impact of the spread in Spain is extreme: a one percentage point increase in the spread predicts roughly a seven percent decline in the (annualized) growth rate of industrial production.

To get a clearer picture of the overall predictive effect of the GZ-spread during the Crisis period, we carry out a simple Wald test of the sum of the coefficients on the GZ-spread and the interaction term. The sixth row of Table 2 reports the outcome of this test. The sum of the coefficients on GZ and GZ*DUM is negative and statistically significant in the three countries on the European periphery. This result holds at all forecasting horizons. The effects of a widening credit spread are also apparent in Germany where a 100 basis point increase in the GZ-spread predicts an almost 3 percent decline in the growth rate of industrial production at the 12 month forecasting horizon. Indeed, three observations are noteworthy. First, the economic significance of widening credit spreads during the Crisis period is remarkable with the sum of the coefficients ranging from -2.44 to well over -4 in the countries on the periphery. Thus, a widening of the GZ-spread by 100 basis points predicts a decrease of up to 4.5 percent in the growth rate of industrial production. Second, the economic significance of the GZ-spread is underscored further by a comparison of the goodness of fit measure in forecasting equations with and without (in bold face) the GZ-spread. Comparing the entries of rows seven and eight in Table 2, we find the adjusted $R^{2}$ drops massively - often by 50 percent or more - if the GZ-spread is omitted from the forecasting equation. Third, in all countries the credit spread appears to exercise a greater effect on the future growth rate of industrial production than the standard measures of monetary policy.

Table 3 summarizes the findings for the unemployment rate. Only in Spain is the term spread an excellent predictor of changes in the unemployment rate across all three horizons. The level of the real short-term money market rate reliably predicts future changes in the 
unemployment rate in Italy at all forecasting horizons while it does so in Germany only at the 12-month horizon. Increases in the inflation differential are positively related to future increases in the unemployment rate in Ireland at all three forecasting horizons but less so for Spain where the inflation differential predicts future changes in the unemployment rate at the 3-month and marginally at the 6-month horizon. In Italy the effect of the inflation differential on the rate of unemployment rate is strongly negative, particularly at the 12-month horizon. This suggests the existence of a Phillips curve effect in Italy.

Just as in the case of industrial production, the GZ-spread appears to have exercised a stronger effect on the rate of unemployment during the Crisis period. Increases in the GZspread during the Crisis period predict higher unemployment rates in Spain, Italy, and Ireland at all forecasting horizons: Wald tests of the significance of the sum of the coefficients on the GZ-spread and GZ*DUM, reported in the sixth row, attest to the strong predictive ability of the GZ-spread during the Crisis period. The marginal effect of the GZ-spread during the Crisis period rises markedly in line with the length of the forecasting horizon in Spain, peaking at 1.51 at the 12 month horizon. A similar pattern is observed in Ireland though the marginal positive impact of credit spread increases on future unemployment rates during the Crisis period is distinctly smaller, peaking at 0.70 at the 12-month horizon. In Italy the marginal effect of the GZ-spread during the Crisis period stays relatively constant over the three forecasting horizons, falling into the 0.5-0.6 range. There is no econometric evidence that the GZ-spread has any predictive ability for the unemployment rate in Germany. Overall, the economic significance of the GZ-spread as a driving factor of future changes in the rate of unemployment is markedly weaker compared to industrial production. Only in Italy and in Ireland at the 12-month horizon does the omission of the GZ-spread and its interaction term result in a substantial drop in the goodness of fit of the forecasting equation.

\section{$\underline{\text { The EMU-Period }}$}

The effective start of the Economic and Monetary Union in January 1999 transformed the financial landscape of Europe. This date saw the introduction of the Euro and, importantly, set in motion a process aiming at even closer financial integration of the European Union. The purpose of this section is to examine whether the effect of the GZ-credit spread on economic activity intensified as a result of the establishment of the EMU at the turn of the millennium. Portugal now joins the list of countries for which this analysis is undertaken. 
Inspection of Table 4 reveals that from 1999 to 2012 the predictive ability of equation (1) for the growth rate of industrial production improves markedly only in Italy. The adjusted $\mathrm{R}^{2}$ rises substantially across all three forecasting horizons. Notice further that the sum of the coefficients on the GZ-spread and the interaction term in Italy (reported in the sixth row) more than doubles during the EMU period compared to the whole sample period. This result holds at all forecasting horizons and underscores the extraordinary importance of the credit spread as a predictor of future economic activity in Italy during the Crisis period since the start of the currency union. For Portugal the results are less clear. On the one hand, there is strong evidence of a connection between increases in the GZ-spread and future changes in economic activity at the 6-month and 12-month horizon, particularly during the Crisis period. On the other hand, the economic significance of the GZ-spread as a predictor appears to be low as the adjusted $R^{2}$ of the forecasting equation without the GZ-spread is about the same as the one with it included. For the other countries, the economic significance of the GZ-spread remains unscathed as the goodness of fit of the forecasting equation without the spread decreases markedly.

We also observe notable changes in the transmission mechanism of monetary policy and the predictive ability of the GZ-spread in more recent times. According to Table 4, changes have been particularly acute in Germany. The results of the Wald test reported in row 6 suggest that the credit spread exercises an immense effect on changes in industrial production at the 3-month horizon during the Crisis period; this effect wanes, however, both in terms of economic and statistical significance as the forecasting horizon increases. What is interesting about Germany (and Ireland) is that the forecasting ability of the GZ-credit spread at the 3month horizon is not limited to the Crisis period but holds throughout the EMU period. In marked contrast, at the 12-month horizon the marginal effect of the GZ-spread on future industrial production seems entirely confined to the Crisis period in Germany. Furthermore, in Germany the interest rate channel also seems more potent while the term spread loses its predictive power altogether during the EMU period.

Table 5 reports the results for the forecasting equation where the rate of unemployment is the dependent variable. Again we observe that for Italy the predictive ability of the forecasting equation is markedly better during the EMU period than over the whole sample period and that the effect of the GZ-spread on future changes in the unemployment rate appears to be stronger during the EMU period than before. Indeed in Italy movements in the GZ-spread predict changes in the unemployment rate at the 3-month and 6-month horizon, respectively, 
well before the start of the Crisis period; the effects of these movements in the GZ-spread on future unemployment intensify during the Crisis period. In Portugal the results suggest that a one percentage point increase in the credit spread during the Crisis period is associated with roughly a one percentage point increase in the rate of unemployment at the 3-month and 6month horizon. For Germany we detect no systematic relationship between the GZ-spread and the rate of unemployment during the EMU period. Overall, the economic significance of the GZ-spread remains strong during the EMU period in Spain, Italy, Ireland and Portugal as evidenced by the substantial decrease in the adjusted $R^{2}$ of the forecasting equation without the GZ-spread and the interaction term.

\section{Quarterly Results}

The marginal predictive effect of the GZ-spread is also tested on quarterly observations of real GDP. Tables 6 and 7 present the econometric results for the whole sample period and the EMU period, respectively. Overall, the findings of Table 6, which attest to a firm link between the GZ-spread and the growth rate of GDP over 1, 2, and 4 quarters, amplify the monthly results between the GZ-spread and industrial production. The GZ-spread predicts future economic growth in Italy and Ireland. ${ }^{19}$ During the Crisis period the negative predictive effect on future economic activity intensifies in Italy and Ireland and particularly in Spain. In the latter country the negative impact effect on GDP growth of a rise in the GZspread during the Crisis period increases in line with the forecasting horizon, peaking at slightly over $-1.85 \%$ for a $1 \%$ increase in the GZ-spread. In the three peripheral countries, the effect of the GZ-spread on real GDP growth at different forecasting horizons falls between -1 and $-2.3 \%$ during the Crisis period. For Germany there is no detectable link between the GZ spread and real GDP growth.

Evidence of the importance of the GZ-spread during the shorter EMU period is found in all countries. ${ }^{20}$ The effect of the GZ-spread on future real activity during the Crisis period is undeniably strong at all three forecasting horizons in all five countries except Germany at the four-quarter horizon: the sum-of-coefficients Wald tests reported in the fifth row of Table 7 clearly reject the null hypothesis that the GZ-spread during the Crisis period exercises no effect on future GDP growth rates. However, there are slight differences across the countries in the way the GZ-spread exercises the predicted negative effect on the growth rate of real

\footnotetext{
${ }^{19}$ The sample period for quarterly observations of real GDP in Ireland begins only in 1997.

${ }^{20}$ The results reported in Table 6 for the 1998:2-2011:12 period in Ireland are very similar to those obtained for the slightly shorter EMU period. Hence the latter are not reported.
} 
GDP. In Italy, for instance, the effect of the GZ-spread on real GDP $\left(c_{3}\right)$ predates the Crisis period and its negative impact $\left(c_{3}+c_{4}\right)$ rises substantially during the Crisis period. In Spain, the effect on real GDP growth materializes exclusively during the Crisis period. In Germany, in contrast, the predictive ability of the GZ-spread at the one-quarter forecast horizon is evident even before the onset of the Global Financial Crisis; there is no separate marginal effect during the Crisis period. ${ }^{21}$ The economic significance of the GZ-spread and the interaction term as predictors of future economic activity is impressive across the board. Omitting both variables from the forecasting specification leads to a massive decrease in the adjusted $R^{2}$ for all countries but Spain at the one-quarter horizon where the decrease in the predictive ability is only 12 percent. In Portugal, the GZ-spread and the interaction term are the only variables that have predictive power over a four-quarter forecasting horizon. Dropping both from the forecasting equation results in a negative adjusted $R^{2}$ !

\section{$\underline{\text { Discussion }}$}

On balance, the GZ spread has more predictive power for economic activity in countries on the periphery than in the centre of Europe. One plausible explanation for the difference in results for Germany and the periphery, especially during the Crisis period, is related to the ease with which non-financial firms were able to switch between alternative sources of finance. In Germany, battling rising funding costs during the Global Financial Crisis, banks began to retrench by shrinking their balance sheets. Against the backdrop of domestic banks' tighter lending requirements and invitingly low corporate bond yields relative to bank lending rates, German companies found it increasingly attractive to tap into the corporate bond market. Kaya and Meyer (2013) report that in 2009 new issues of corporate bonds in Germany were a record $€ 30$ billion, dropped off a bit in 2010 and 2011 but remained high to the end of the sample period. In marked contrast companies in the peripheral countries scrambled to raise funding. They were squeezed by adverse developments in both the domestic banking sector and the corporate debt market. The increase in sovereign risk in the countries on the periphery led to a significant deterioration of banks' funding conditions and lending capacity. DeMarco (2015) reports a significant drop in the supply of bank loans in the countries on the periphery where banks had significant holdings of impaired government debt on their books right after the start of the Sovereign Debt Crisis. The same author as well as

\footnotetext{
${ }^{21}$ For Portugal, the standard errors of the coefficient estimates on the first differences of GZ and GZ*DUM are highly inflated due to severe multicollinearity. The correlation coefficient for the two regressors is 0.95 . A similar problem, though less serious, applies to the standard errors estimated for Germany. The correlation coefficient for GZ and GZ*DUM is 0.80 for Germany.
} 
Neri and Ropelo (2014) report that in 2011 the cost of new business loans started rising much faster in Italy, Spain, and Portugal than in Germany. The deterioration in the perceived creditworthiness of the domestic sovereign thus had undesirable consequences for borrowers in terms of the supply and cost of bank-financed credit.

During the Sovereign Debt Crisis corporate bond yields in the countries on the periphery surged because corporate risk cannot be divorced from sovereign risk. A domestic sovereign whose creditworthiness appears doubtful infects domestic corporate borrowers in the bond market, making the acquisition of bond-financed credit costly. Due to the high cost of borrowing, the issuance of new corporate debt fell to very low levels in Italy, Portugal, and Spain in 2011..$^{22,23}$ Thus firms in countries on the periphery encountered stiff headwinds in securing bank-financed credit as well as accessing the corporate bond market as the Debt Crisis unfolded. Both developments account for the slowdown in economic activity in Southern Europe towards the end of the sample period. ${ }^{24}$

\section{Conclusion}

In February 2013, the annual yield on long-term (10-year) government bonds within the EMU varied greatly. In the centre, the yield on German Bunds stood at 1.54 percent while on the periphery yields were at least double the German yield (Ireland at 3.78 percent), thrice the German yield (Italy at 4.49 percent, Spain at 5.22 percent), and more than fourfold the German yield (Portugal at 6.40 percent). ${ }^{25}$ The dramatic difference in yields is due to country-specific perceptions of risk and underscores the apparent fragmentation of European public debt markets which has set in with the beginning of the Crisis period in 2007.

\footnotetext{
${ }^{22}$ Downgrades of sovereigns typically lead to downgrades of banks or non-financial corporations as the rating of a sovereign acts as a ceiling for the rating of the latter. See the CGFS Paper No. 43, 2011 for a detailed account of the effect of sovereign credit risk on bank funding conditions.

${ }^{23}$ For Ireland data on corporate borrowing has been published by the ECB only since 2010. Italy's corporate bond market is relatively more developed and more important as a source of corporate borrowing than Spain's or Portugal's. In 2009, new corporate borrowing in Italy amounted to approx. $€ 15$ billion while in Spain and Portugal it was less than $€ 4$ billion. In 2011 issuance of new corporate bonds plunged to $€ 6.9$ billion in Italy, $€$ 1 billion in Spain, and $€ 1.5$ billion in Portugal.

${ }^{24}$ In 2012 the situation in the corporate bond markets in Italy, Portugal, and Spain began to ease. Corporate borrowing increased substantially in all three countries but its effect on economic activity cannot be investigated as the sample period ends in 2012.

${ }^{25}$ All data were retrieved from the Statistical Warehouse maintained by the European Central Bank. Table A1 in the appendix gives an overview of yields on government bonds from 1993 to the recent past.
} 
The current disruption of the European capital market must be put in perspective. In July 2007, before the outbreak of the Global Financial Crisis, the difference between the highest yield on 10-year government bonds (Italy at 4.76 percent) and the lowest yield (Germany at 4.50 percent) was a paltry 26 basis points. In April 2012, at the conclusion of the sample period of our study, the highest yield difference on the same instruments was a staggering 1018 basis points (Portugal at 12.01 percent and Germany at 1.83 percent).

In the countries on the European periphery, the adverse developments in the public debt market have also spilled into the corporate debt market. Corporate bonds issued in these countries have been saddled with a burdensome risk premium which derives largely from the riskiness associated with domestic government debt and rising uncertainty about the prospects of the EMU.

In this paper we examine whether the pricing of risk is important for macroeconomic activity at the country level. Drawing on a representative sample of corporate bonds outstanding, we design a risk-adjusted yield spread and test its predictive content for economic activity on the periphery and the centre of Europe. The sample period runs from 1990 to 2012. The sample period is thus long enough to take account of distinctly different epochs in recent European financial history. Capital markets in Europe were still very fairly segmented and characterized by material borrowing cost differentials at the start of the 1990s. The drive towards forming the EMU saw the eventual removal of all barriers to the free flow of capital, the convergence of interest rates, and the elimination of exchange rate risk. The vision to create a single European capital market first encountered problems with the outbreak of the Global Financial Crisis and was dealt a severe blow when the Sovereign Debt Crisis created havoc in the capital markets on the European periphery.

At the centre of our analysis is a risk-adjusted bond yield spread defined in a cross-country context. Increases in the yield on corporate bonds issued in the countries on the periphery relative to the riskless yield (calculated using German zero-coupon term structure data) reflect increases in the risk premium that the financial market imposes on borrowers. The risk premium rises in all countries during European-wide recessions of the recent past, particularly those associated with the Global Financial and the Sovereign Debt Crisis. Our findings indicate further that this GZ-type spread acts as a reliable signal for imminent and near-term economic activity in the countries on the European periphery whose banking and capital markets were shaken to their foundations during the Crisis period. The paper also 
employs the GZ-spread for forecasting purposes in a within-country context. For Germany, the GZ-spread has predictive content for industrial production but not for the unemployment rate. For GDP its predictive ability is confined to the EMU period at very short horizons. 


\section{References:}

Ang A, Piazzesi M, Wei M (2006) What does the yield curve tell us about GDP growth? J of Econom 131: 359-403.

Bernanke BS (1990) On the predictive power of interest rates and interest rate spreads. $N$ Engl Econ Rev Nov - Dec: 51-68.

Bernanke B, Gertler M (1995) Inside the black-box - the credit channel of monetary-policy transmission. J of Econ Persp 9: 27-48.

Bernanke B, Gertler M, Gilchrist S (1996) The financial accelerator and the flight to quality. Rev of Econ and Stat 78: 1-15.

Bernanke B, Gertler M, Gilchrist S (1999) The financial accelerator in a quantitative business cycle framework. In: handbook of macroeconomics vol. 1C, Elsevier, Amsterdam, pp $1341-1393$

Bleaney M, Mizen P, Veleanu P (2012) Credit spreads as predictors of economic activity in eight european economies. Mimeo, University of Nottingham.

Chan-Lau JA, Ivaschenko IV (2001) Corporate bond risk and real activity: an empirical analysis of yield spreads and their systematic components. Mimeo, International Monetary Fund.

Committee on the Global Financial System (2011) The impact of sovereign credit risk on bank funding conditions, CFGS Papers, No 43. Bank for International Settlements.

Davis EP, Fagan G (1997) Are financial spreads useful indicators of future inflation and output growth in eu countries? J of Appl Economet 12:701-714.

De Bondt G (2004) The balance sheet channel of monetary policy: first empirical evidence for the euro area corporate bond market. Intern J of Fin \& Econ 9: 219-228.

Emery KM (1996) The information content of the paper-bill spread. J of Econ and Bus 48: 110.

Estrella A, Hardouvelis G (1991) The term structure as a predictor of real economic activity. J of Fin 46: 555-576.

Financial Times European Company Borrowing Costs Rise. November 30, 2010.

Financial Times Loan Rates Point to Eurozone Fractures. September 3, 2012.

Friedman B, Kuttner K (1992) Money, income, prices, and interest rates. Am Econ Rev 82: 472-492.

Gertler M, Lown CS (1999) The information in the high-yield bond spread for the business cycle: evidence and some implications. Oxf Rev of Econ Pol 15: 132-150. 
Gilchrist S, Zakrajšek E (2012) Credit spreads and business cycle fluctuations. Am Econ Rev 102: 1692-1720.

Harvey CR (1988) The real term structure and consumption growth. J of Fin Econ 22: 305322.

Hubbard, G (1995) Is there a "credit channel” for monetary policy. Review (Fed Res Bank of St. Louis) 77: 63-77.

Kaya O, Meyer T (2013) Corporate Bond Issuance in Europe. EU Monitor, Deutsche Bank Research, January $31^{\text {st }}$.

King TB, Levin AT, Perli R (2007) Financial market perceptions of recession risks. Fin and Econ Disc Series 2007-57, Board of Governors of the Federal Reserve System.

Mody A, Taylor MP (2004) Financial predictors of real activity and the financial accelerator. Econ Let 82: 167-172.

Moersch M (1996) Predicting output with a money market spread. J of Econ and Bus 2: 185200.

Mueller P (2009) Credit spreads and real activity. Mimeo, London School of Economics.

Neri S, Ropele T (2014) The macroeconomic effects of the sovereign debt crisis in the euro area, mimeo.

Stock JH, Watson MW (2003) Forecasting output and inflation: the role of asset prices. $J$ of Econ Lit 41: 788-829.

Wall Street Journal Bonds with Banks Fraying. April 10, 2012. 
Figure 1: The GZ-Spread in Europe

\section{SPAIN}

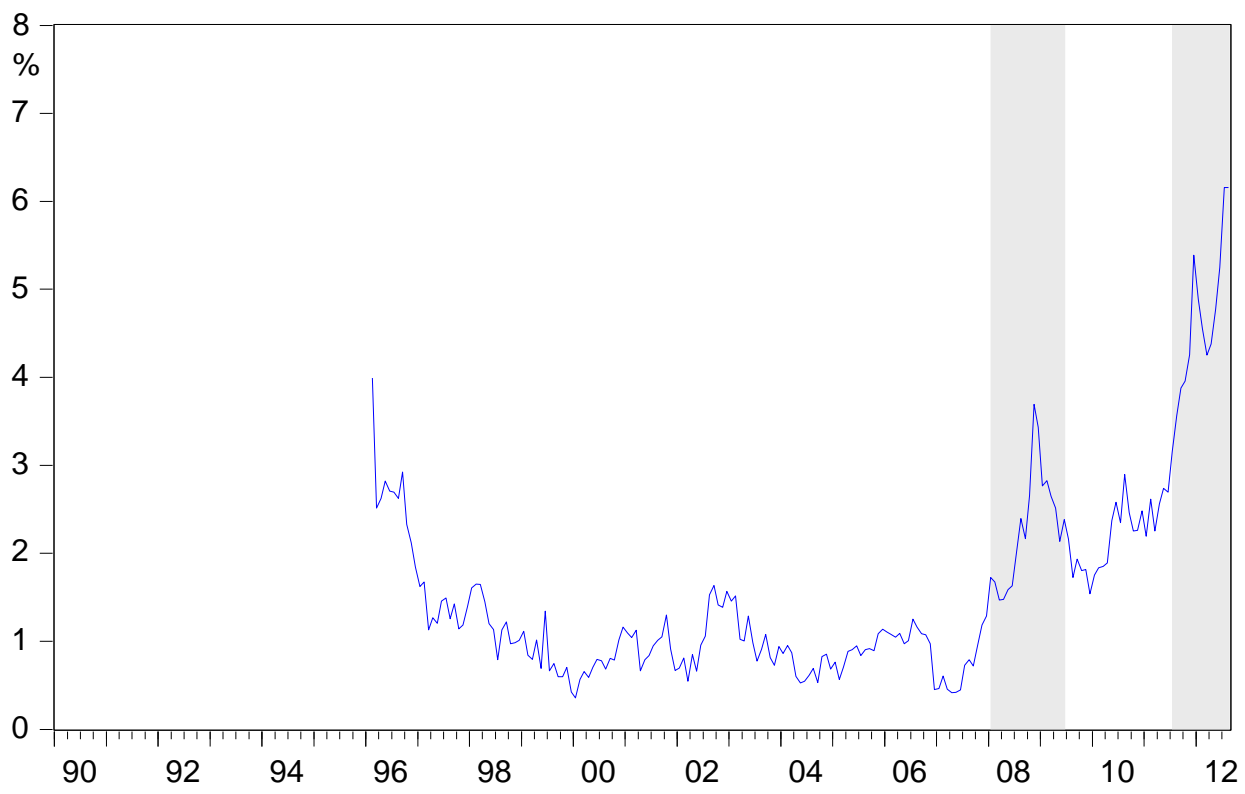

ITALY

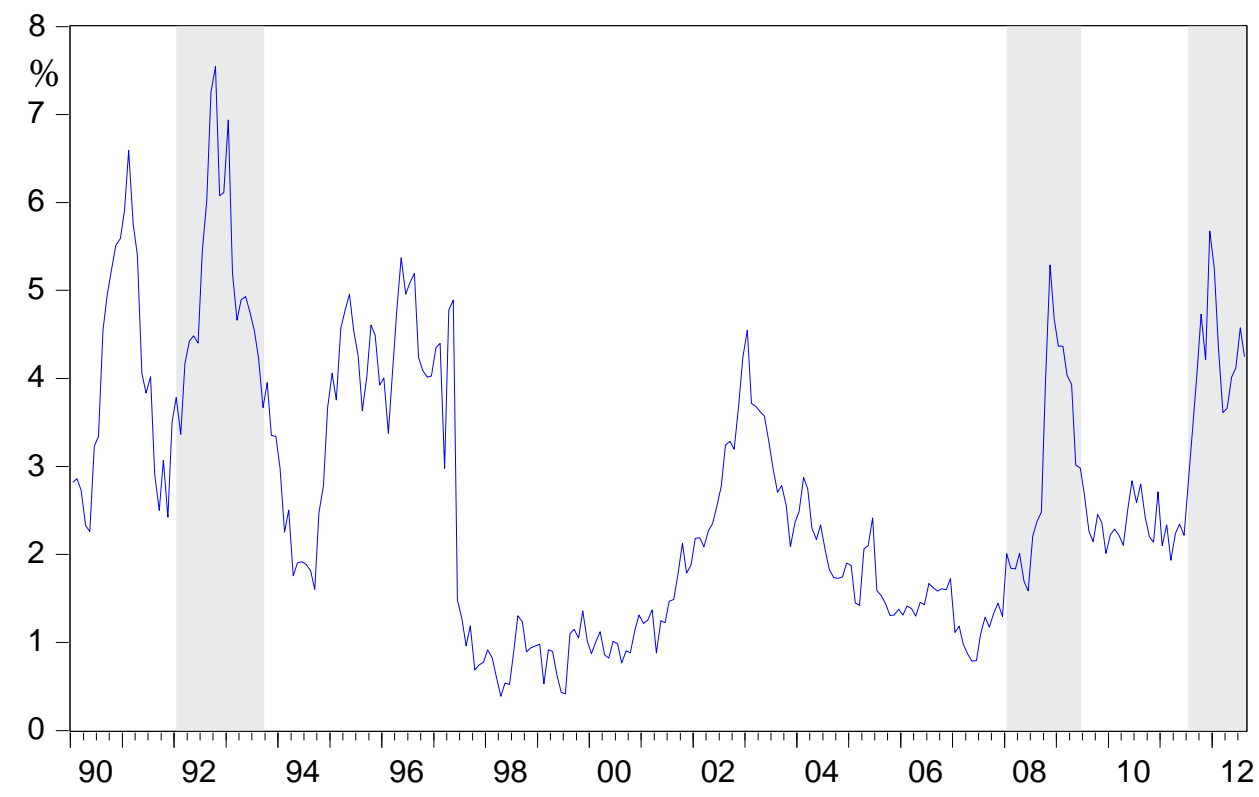

Note: The shaded areas represent European-wide recessions. 
IRELAND

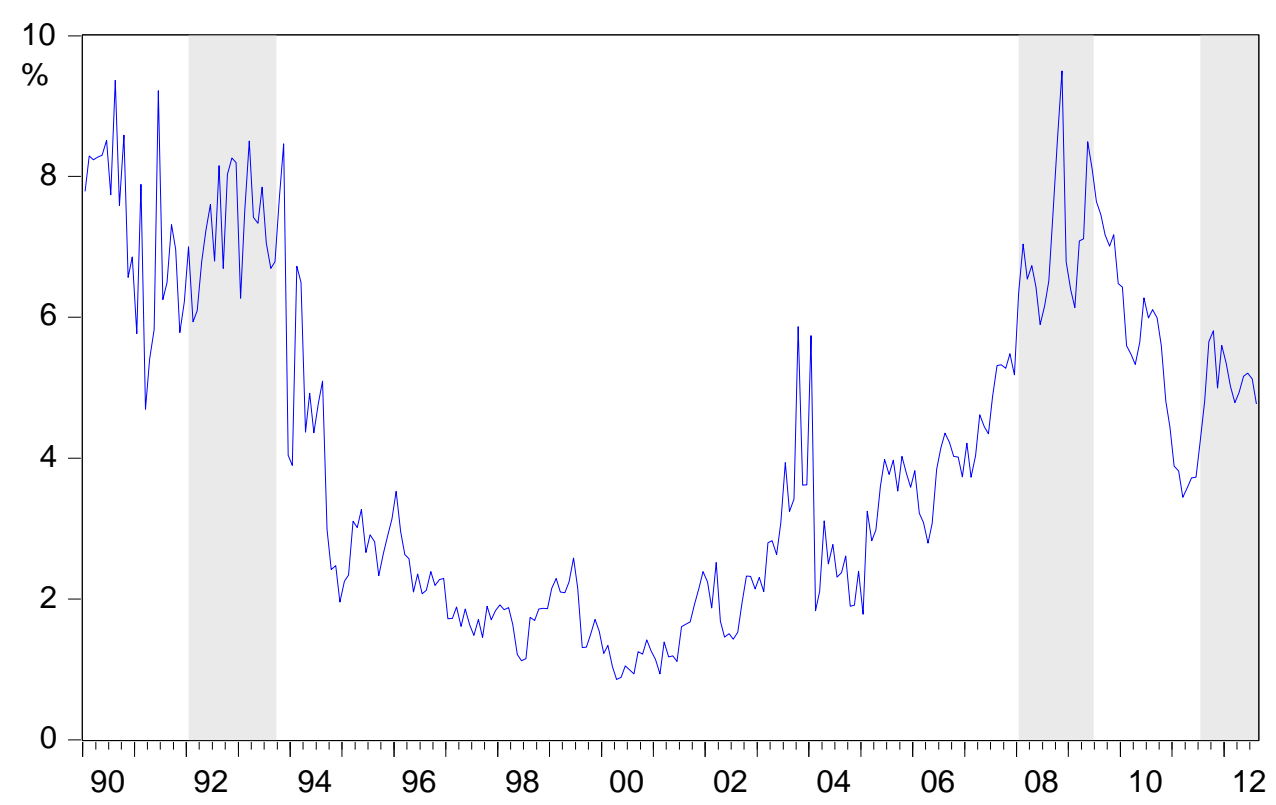

PORTUGAL

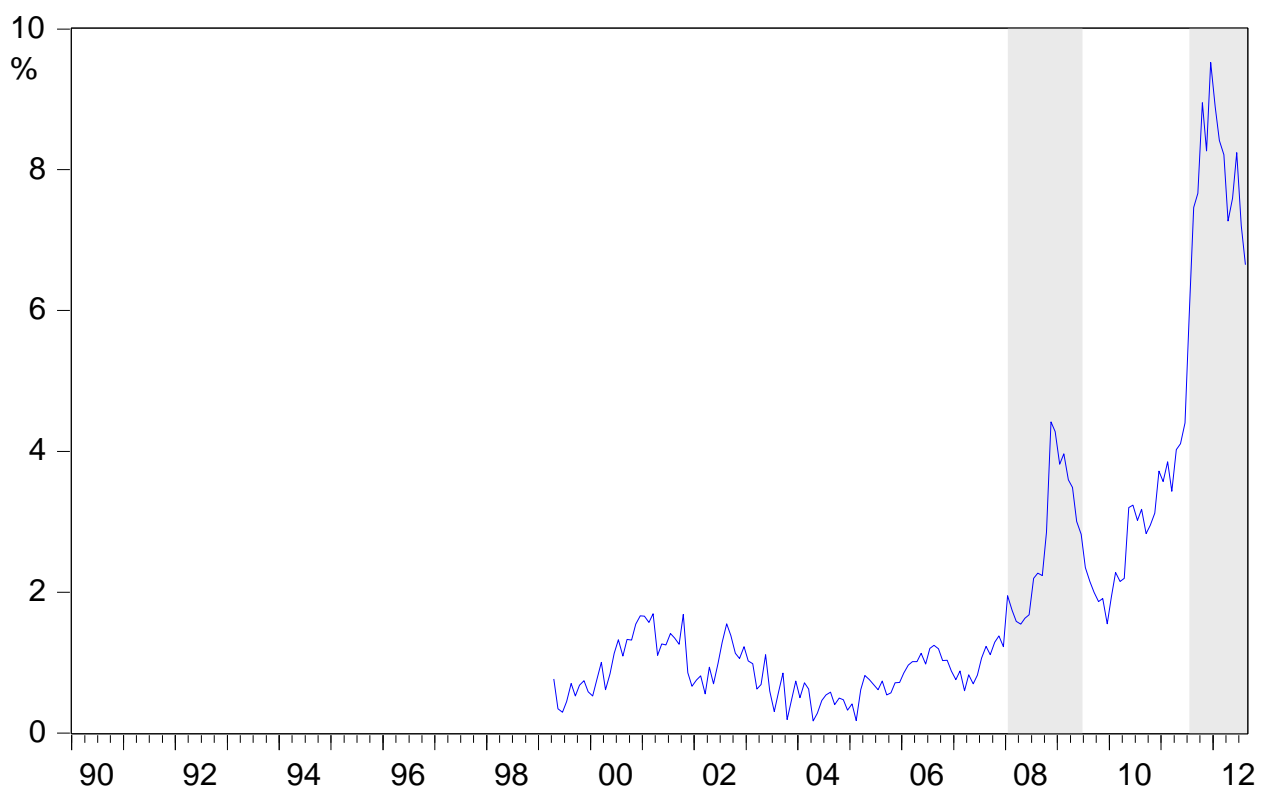


GERMANY

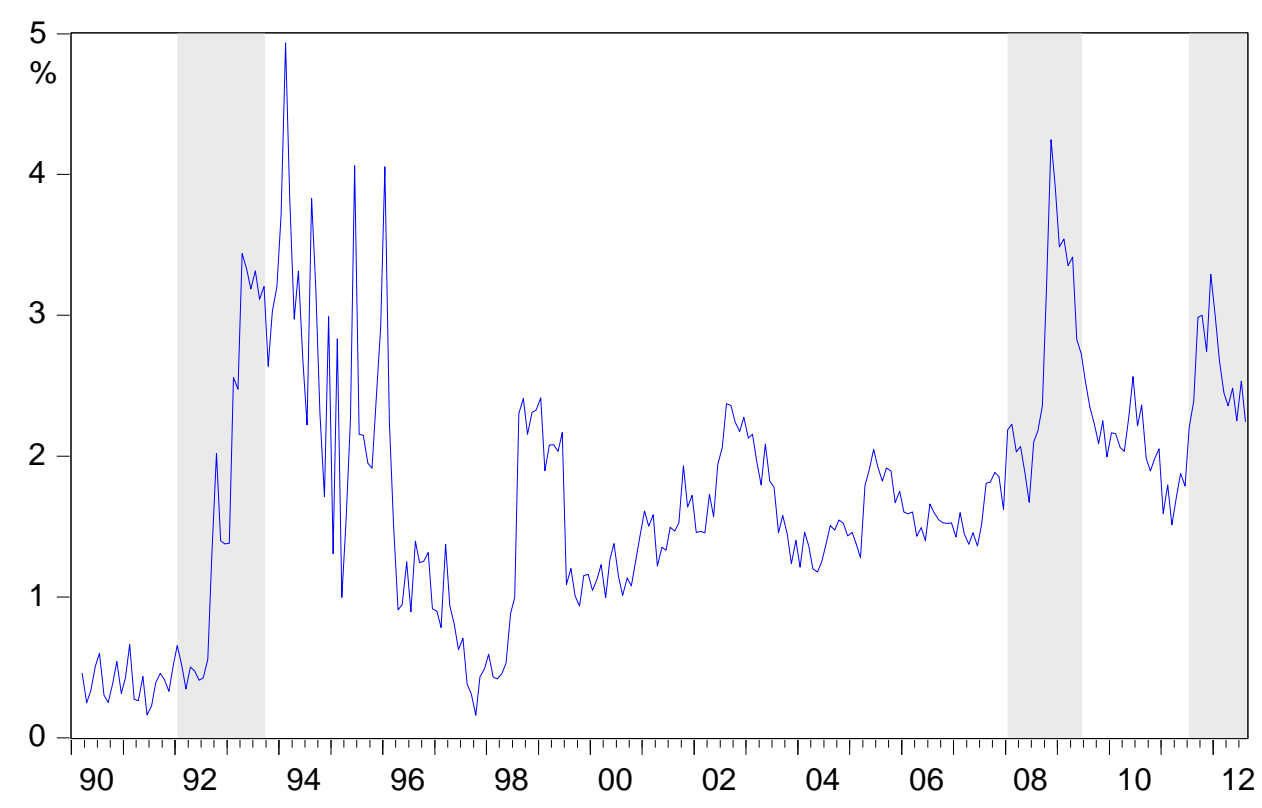


Table 1A: Summary Statistics

\begin{tabular}{|c|c|c|c|c|c|}
\hline & Spain & Italy & Germany & Portugal & Ireland \\
\hline Mean No. of bonds per firm & 4.61 & 4.32 & 5.29 & 3.00 & 4.69 \\
\hline Standard deviation & 4.30 & 6.91 & 6.97 & 4.24 & 7.89 \\
\hline Min No. of bonds per firm & 1.00 & 1.00 & 1.00 & 1.00 & 1.00 \\
\hline Max No. of bonds per firm & 16.00 & 37.00 & 35.00 & 13.00 & 30.00 \\
\hline Total number of bonds & 75 & 174 & 330 & 42 & 59 \\
\hline Total number of observations & 4,085 & 8,251 & 14,953 & 1,781 & 2,938 \\
\hline Total number of issuing firms & 17 & 41 & 62 & 13 & 13 \\
\hline Mean maturity at issue (yrs.) & 11.81 & 8.37 & 6.93 & 7.1 & 12.76 \\
\hline Standard deviation & 8.94 & 6.14 & 4.1 & 4.72 & 11.37 \\
\hline Mean coupon & $5.45 \%$ & $5.79 \%$ & $5.35 \%$ & $5.46 \%$ & $10.74 \%$ \\
\hline Standard deviation & $1.73 \%$ & $1.79 \%$ & $1.94 \%$ & $1.09 \%$ & $24.49 \%$ \\
\hline Mean yield & $4.93 \%$ & $5.59 \%$ & $4.56 \%$ & $5.68 \%$ & $8.10 \%$ \\
\hline Standard deviation & $1.63 \%$ & $2.54 \%$ & $2.17 \%$ & $2.43 \%$ & $5.64 \%$ \\
\hline $\begin{array}{l}\text { Median bond credit rating } \\
(\mathrm{S} \& \mathrm{P})\end{array}$ & $\mathrm{BBB}$ & $\mathrm{BBB}$ & $\mathrm{BBB}+$ & $\mathrm{BB}+$ & A \\
\hline Series start (all end 2012M08) & 1996M02 & 1990M01 & 1990M03 & 1999M04 & 1990M01 \\
\hline
\end{tabular}

Note:

a. 'Total number of observations' refers to the total number of spreads in each country. 
Table 1B: Summary Statistics for GZ-Spread

1B.1 Whole Sample Period

\begin{tabular}{|l|l|l|l|l|}
\hline & Spain & Italy & Ireland & Germany \\
\hline Mean & 1.58 & 2.73 & 4.13 & 1.72 \\
\hline Maximum & 6.16 & 7.54 & 9.50 & 4.93 \\
\hline Minimum & 0.36 & 0.39 & 0.85 & 0.16 \\
\hline Std. Deviation & 1.12 & 1.53 & 2.29 & 0.89 \\
\hline Observations & 199 & 272 & 272 & 270 \\
\hline Sample Period & $1996: 02-2012: 08$ & $1990: 01-2012: 08$ & $1990: 01-2012: 08$ & $1990: 03-2012: 08$ \\
\hline
\end{tabular}

1B.2 The Pre-EMU Period

\begin{tabular}{|l|l|l|l|l|}
\hline & Spain & Italy & Ireland & Germany \\
\hline Mean & 1.72 & 3.55 & 4.63 & 1.50 \\
\hline Maximum & 3.99 & 7.54 & 9.37 & 4.93 \\
\hline Minimum & 0.79 & 0.39 & 1.12 & 0.16 \\
\hline Std. Deviation & 0.73 & 1.70 & 2.60 & 1.18 \\
\hline Observations & 35 & 108 & 108 & 106 \\
\hline Sample Period & $1996: 02-1998: 12$ & $1990: 01-1998: 12$ & $1990: 01-1998: 12$ & $1990: 03-1998: 12$ \\
\hline
\end{tabular}

1B.3 The EMU Period (1999:01-2012:08)

\begin{tabular}{|l|l|l|l|l|l}
\hline & Spain & Italy & Ireland & Portuga $*$ & Germany \\
\hline Mean & 1.55 & 2.19 & 3.80 & 1.99 & 1.87 \\
\hline Maximum & 6.16 & 5.68 & 9.50 & 9.53 & 4.25 \\
\hline Minimum & 0.36 & 0.42 & 0.85 & 0.17 & 0.93 \\
\hline Std. Deviation & 1.18 & 1.12 & 2.00 & 2.10 & 0.59 \\
\hline Observations & 164 & 164 & 164 & 161 & 164 \\
\hline
\end{tabular}

1B.4 The Pre-Crisis Period (1999:01-2007:07)

\begin{tabular}{|l|l|l|l|l|l}
\hline & Spain & Italy & Ireland & Portugal* & Germany \\
\hline Mean & 0.88 & 1.77 & 2.57 & 0.86 & 1.57 \\
\hline Maximum & 1.64 & 4.55 & 5.87 & 1.69 & 2.41 \\
\hline Minimum & 0.36 & 0.42 & 0.85 & 0.17 & 0.93 \\
\hline Std. Deviation & 0.28 & 0.88 & 1.16 & 0.37 & 0.34 \\
\hline Observations & 103 & 103 & 103 & 100 & 103 \\
\hline
\end{tabular}

1B.5 The Crisis Period (2007:08-2012:08)

\begin{tabular}{|l|l|l|l|l|l}
\hline & Spain & Italy & Ireland & Portugal & Germany \\
\hline Mean & 2.68 & 2.89 & 5.87 & 3.85 & 2.37 \\
\hline Maximum & 6.16 & 5.68 & 9.50 & 9.53 & 4.25 \\
\hline Minimum & 0.72 & 1.17 & 3.44 & 1.11 & 1.51 \\
\hline Std. Deviation & 1.26 & 1.13 & 1.28 & 2.42 & 0.59 \\
\hline Observations & 61 & 61 & 61 & 61 & 61 \\
\hline
\end{tabular}

*Sample Period begins in 1999:04 


\begin{tabular}{|c|c|c|c|c|c|c|c|c|c|c|c|c|}
\hline & \multicolumn{12}{|c|}{ Table 2 - Industrial Production } \\
\hline & \multirow[b]{2}{*}{ Spain } & \multicolumn{3}{|c|}{ Forecast Horizon $=\mathbf{3}$ months } & \multicolumn{4}{|c|}{ Forecast Horizon $=6$ months } & \multirow[b]{2}{*}{ Spain } & \multicolumn{3}{|c|}{ Forecast Horizon $=12$ months } \\
\hline & & Italy & Ireland & Germany & Spain & Italy & Ireland & Germany & & Italy & Ireland & Germany \\
\hline Term Spread & $\begin{array}{l}2.32 * * \\
{[1.00]}\end{array}$ & $\begin{array}{l}0.76^{*} \\
{[0.42]}\end{array}$ & $\begin{array}{l}-0.80 \\
{[0.52]}\end{array}$ & $\begin{array}{l}2.19 * * * \\
{[0.78]}\end{array}$ & $\begin{array}{l}2.57 * * * \\
{[1.36]}\end{array}$ & $\begin{array}{c}0.57 \\
{[0.52]}\end{array}$ & $\begin{array}{l}-0.62 * \\
{[0.37]}\end{array}$ & $\begin{array}{l}2.29 * * * \\
{[0.79]}\end{array}$ & $\begin{array}{l}3.54 * * * \\
{[1.09]}\end{array}$ & $\begin{array}{l}0.58 \\
{[0.47]}\end{array}$ & $\begin{array}{l}-0.29 \\
{[0.29]}\end{array}$ & $\begin{array}{l}2.31 * * * \\
{[0.90]}\end{array}$ \\
\hline Euribor & $\begin{array}{c}-1.46^{*} \\
{[0.87]}\end{array}$ & $\begin{array}{l}-0.03 \\
{[0.36]}\end{array}$ & $\begin{array}{l}1.05 * * \\
{[0.47]}\end{array}$ & $\begin{array}{l}-1.64 * \\
{[0.94]}\end{array}$ & $\begin{array}{l}-1.55^{* *} \\
{[0.41]}\end{array}$ & $\begin{array}{c}-0.07 \\
{[0.31]}\end{array}$ & $\begin{array}{l}0.73 \\
{[0.47]}\end{array}$ & $\begin{array}{l}-1.29 \\
{[0.69]}\end{array}$ & $\begin{array}{l}-0.97 * \\
{[0.59]}\end{array}$ & $\begin{array}{l}-0.14 \\
{[0.29]}\end{array}$ & $\begin{array}{l}0.48 \\
{[0.36]}\end{array}$ & $\begin{array}{l}-1.02 * * \\
{[0.52]}\end{array}$ \\
\hline GZ & $\begin{array}{c}3.23 \\
{[2.15]}\end{array}$ & $\begin{array}{l}-0.16 \\
{[0.58]}\end{array}$ & $\begin{array}{l}-3.43 * * * \\
{[0.89]}\end{array}$ & $\begin{array}{l}-1.88 \\
{[1.30]}\end{array}$ & $\begin{array}{l}4.29 * * \\
{[1.44]}\end{array}$ & $\begin{array}{c}0.12 \\
{[0.57]}\end{array}$ & $\begin{array}{l}-2.66 * * * \\
{[0.59]}\end{array}$ & $\begin{array}{l}-0.85 \\
{[0.83]}\end{array}$ & $\begin{array}{l}2.89^{*} \\
{[1.64]}\end{array}$ & $\begin{array}{l}0.52 \\
{[0.47]}\end{array}$ & $\begin{array}{l}-1.95^{* * * *} \\
{[0.43]}\end{array}$ & $\begin{array}{l}-0.15 \\
{[0.50]}\end{array}$ \\
\hline GZ*DUM & $\begin{array}{l}-6.94 * * * \\
{[1.23]}\end{array}$ & $\begin{array}{l}-2.84 * * \\
{[1.25]}\end{array}$ & $\begin{array}{l}-1.04 * \\
{[0.64]}\end{array}$ & $\begin{array}{l}-3.20 \\
{[2.03]}\end{array}$ & $\begin{array}{l}-7.88 * * * \\
{[1.19]}\end{array}$ & $\begin{array}{l}-2.69 * * \\
{[1.15]}\end{array}$ & $\begin{array}{l}-1.07 * * \\
{[0.46]}\end{array}$ & $\begin{array}{l}-2.77 * \\
{[1.69]}\end{array}$ & $\begin{array}{l}-7.27 * * * \\
{[1.18]}\end{array}$ & $\begin{array}{l}-2.96 * * * \\
{[1.18]}\end{array}$ & $\begin{array}{l}-0.95 * * * \\
{[0.28]}\end{array}$ & $\begin{array}{l}-2.83 * * \\
{[1.34]}\end{array}$ \\
\hline Inf ${ }^{\text {Home }}-$ Inf ${ }^{\text {Ger }}$ & $\begin{array}{l}-4.06^{* *} \\
{[1.73]}\end{array}$ & - & - & - & $\begin{array}{l}-4.22 * * * \\
{[1.57]}\end{array}$ & - & - & - & $\begin{array}{l}-2.29 * * \\
{[1.07]}\end{array}$ & - & $\begin{array}{l}-1.32 * * * \\
{[0.41]}\end{array}$ & - \\
\hline$c_{3}+c_{4}=0$ & $\begin{array}{l}-3.71 * * * \\
{[0.95]}\end{array}$ & $\begin{array}{l}-3.00 * * * \\
{[1.07]}\end{array}$ & $\begin{array}{l}-4.47 * * * \\
{[0.74]}\end{array}$ & $\begin{array}{l}-5.08 * \\
{[2.88]}\end{array}$ & $\begin{array}{l}-3.59 * * * \\
{[0.97]}\end{array}$ & $\begin{array}{l}-2.57 * * * \\
{[0.91]}\end{array}$ & $\begin{array}{l}-3.73 * * * \\
{[0.57]}\end{array}$ & $\begin{array}{l}-3.62 * \\
{[2.04]}\end{array}$ & $\begin{array}{l}-4.38 * * * \\
{[1.09]}\end{array}$ & $\begin{array}{l}-2.44 * * \\
{[1.05]}\end{array}$ & $\begin{array}{l}-2.90 * * * \\
{[0.34]}\end{array}$ & $\begin{array}{l}-2.98 * * \\
{[1.47]}\end{array}$ \\
\hline $\begin{array}{l}\text { Adj. R2 } \\
\text { Adj. R2 } \\
\text { without GZ }\end{array}$ & 0.46 & 0.27 & 0.31 & 0.24 & 0.56 & 0.24 & 0.35 & 0.27 & 0.61 & 0.23 & 0.48 & $\begin{array}{l}0.35 \\
\mathbf{0 . 2 2}\end{array}$ \\
\hline Obs. & 195 & 255 & 255 & 255 & 192 & 252 & 252 & 252 & 186 & 246 & 246 & 246 \\
\hline Sample start & 1996M02 & 1991M02 & 1991M02 & 1991M02 & 1996M02 & 1991M02 & 1991M02 & 1991M02 & 1996M02 & 1991M02 & 1991M02 & 1991M02 \\
\hline Sample end & 2012M04 & 2012M04 & 2012M04 & 2012M04 & 2012M01 & 2012M01 & 2012M01 & 2012M01 & 2011M07 & 2011M07 & 2011M07 & 2011M07 \\
\hline
\end{tabular}

Notes:

a. All estimated regressions are based on monthly data and include 12 lags of the log difference of industrial production $\left(\nabla y_{t}\right)$ :

$$
\nabla^{h} y_{t+h}=b_{0}+\sum_{i=1}^{12} b_{i} \nabla y_{t-i}+c_{1} T S_{t}+c_{2} E U_{t}+c_{3} G Z_{t}+c_{4} G Z_{t} * D U M_{t}+c_{5}\left(I N F_{t}^{H o m e}-I N F_{t}^{G e r}\right)+\epsilon_{t+h}
$$




$$
\text { Where } \nabla^{h} y_{t+h}=\frac{c}{h+1} \ln \left(\frac{Y_{t+h}}{Y_{t-1}}\right) \quad h=3,6,12 \text { (forecast horizon) } \quad c=1200 \text { (scaling constant for monthly data) }
$$

b. The term spread $(T S)$ is defined as the yield on 10-year government bonds minus the yield on 1-year government paper. For each country, the short-term interest rate $(E U)$ has been adjusted for inflation (Nominal Euribor minus CPI inflation). Inflation is calculated as $100 *\left(\ln \left(C P I_{t}\right)-\ln \left(C P I_{t-12}\right)\right)$. The dummy variable $(D U M)$ takes on value 1 from 2007M08 onward and zero otherwise. August 2007 marks the beginning of the Great Financial Crisis. INF ${ }^{\text {Home }}$-INF $F^{\text {Ger }}$ is the inflation differential in the home country relative to Germany. Home = Spain, Italy, Ireland, Portugal.

c. $10 \%$ significance is denoted by*, $5 \%$ by $* *$ and $1 \%$ by $* * *$. Newey-West standard errors are in brackets with coefficient estimates reported directly above.

d. Sum of coefficient estimates reported may be slightly different due to rounding errors. 


\begin{tabular}{|c|c|c|c|c|c|c|c|c|c|c|c|c|}
\hline \multicolumn{13}{|c|}{ Table 3 - Unemployment } \\
\hline & \multicolumn{4}{|c|}{ Forecast Horizon $=3$ months } & \multicolumn{4}{|c|}{ Forecast Horizon $=6$ months } & \multicolumn{4}{|c|}{ Forecast Horizon = 12 months } \\
\hline & Spain & Italy & Ireland & Germany & Spain & Italy & Ireland & Germany & Spain & Italy & Ireland & Germany \\
\hline Term Spread & $\begin{array}{l}-0.43 * * \\
{[0.19]}\end{array}$ & $\begin{array}{l}0.05 * \\
{[0.03]}\end{array}$ & $\begin{array}{l}-0.03 \\
{[0.05]}\end{array}$ & $\begin{array}{l}-0.01 \\
{[0.06]}\end{array}$ & $\begin{array}{l}-0.74 * * * \\
{[0.22]}\end{array}$ & $\begin{array}{l}0.03 \\
{[0.03]}\end{array}$ & $\begin{array}{l}-0.06 \\
{[0.06]}\end{array}$ & $\begin{array}{l}0.02 \\
{[0.79]}\end{array}$ & $\begin{array}{l}-1.30 * * * \\
{[0.27]}\end{array}$ & $\begin{array}{l}-0.01 \\
{[0.03]}\end{array}$ & $\begin{array}{l}-0.02 \\
{[0.04]}\end{array}$ & $\begin{array}{l}0.11 \\
{[0.10]}\end{array}$ \\
\hline Euribor & $\begin{array}{l}0.26 \\
{[0.19]}\end{array}$ & $\begin{array}{l}0.14 * * * \\
{[0.04]}\end{array}$ & $\begin{array}{l}0.02 \\
{[0.02]}\end{array}$ & $\begin{array}{l}0.11 \\
{[0.08]}\end{array}$ & $\begin{array}{l}0.23 \\
{[0.19]}\end{array}$ & $\begin{array}{l}0.14 * * * \\
{[0.03]}\end{array}$ & $\begin{array}{l}0.01 \\
{[0.02]}\end{array}$ & $\begin{array}{l}0.14 \\
{[0.09]}\end{array}$ & $\begin{array}{l}-0.02 \\
{[0.11]}\end{array}$ & $\begin{array}{l}0.14 * * * \\
{[0.03]}\end{array}$ & $\begin{array}{l}-0.00 \\
{[0.02]}\end{array}$ & $\begin{array}{l}0.27 * * * \\
{[0.10]}\end{array}$ \\
\hline GZ & $\begin{array}{l}-0.68^{*} \\
{[0.40]}\end{array}$ & $\begin{array}{l}0.05 \\
{[0.06]}\end{array}$ & $\begin{array}{l}0.17 * * \\
{[0.07]}\end{array}$ & $\begin{array}{l}-0.00 \\
{[0.06]}\end{array}$ & $\begin{array}{l}-0.56 \\
{[0.42]}\end{array}$ & $\begin{array}{l}0.10 \\
{[0.06]}\end{array}$ & $\begin{array}{l}0.21 * * * \\
{[0.07]}\end{array}$ & $\begin{array}{l}-0.02 \\
{[0.08]}\end{array}$ & $\begin{array}{l}0.21 \\
{[0.31]}\end{array}$ & $\begin{array}{l}0.11 * * \\
{[0.05]}\end{array}$ & $\begin{array}{l}0.28 * * * \\
{[0.07]}\end{array}$ & $\begin{array}{l}-0.09 \\
{[0.09]}\end{array}$ \\
\hline GZ*DUM & $\begin{array}{l}1.41 * * * \\
{[0.51]}\end{array}$ & $\begin{array}{l}0.49 * * * \\
{[0.10]}\end{array}$ & $\begin{array}{l}0.26 * * * \\
{[0.07]}\end{array}$ & $\begin{array}{l}0.05 \\
{[0.12]}\end{array}$ & $\begin{array}{l}1.45 * * * \\
{[0.50]}\end{array}$ & $\begin{array}{l}0.47 * * * \\
{[0.09]}\end{array}$ & $\begin{array}{l}0.32 * * * \\
{[0.08]}\end{array}$ & $\begin{array}{l}0.04 \\
{[0.13]}\end{array}$ & $\begin{array}{l}1.30 * * * \\
{[0.36]}\end{array}$ & $\begin{array}{l}0.47 * * * \\
{[0.10]}\end{array}$ & $\begin{array}{l}0.42 * * * \\
{[0.09]}\end{array}$ & $\begin{array}{l}0.00 \\
{[0.13]}\end{array}$ \\
\hline $\mathrm{Inf}^{\mathrm{Home}}-\mathrm{Inf}^{\mathrm{Ger}}$ & $\begin{array}{l}0.77 * * \\
{[0.38]}\end{array}$ & - & $\begin{array}{l}0.31 * * * \\
{[0.08]}\end{array}$ & - & $\begin{array}{l}0.77^{*} \\
{[0.40]}\end{array}$ & $\begin{array}{l}-0.10^{*} \\
{[0.06]}\end{array}$ & $\begin{array}{l}0.38 * * * \\
{[0.08]}\end{array}$ & - & - & $\begin{array}{l}-0.13^{* * *} \\
{[0.04]}\end{array}$ & $\begin{array}{l}0.46^{* * * *} \\
{[0.07]}\end{array}$ & - \\
\hline$c_{3}+c_{4}=0$ & $\begin{array}{l}0.73 * * * \\
{[0.23]}\end{array}$ & $\begin{array}{l}0.54 * * * \\
{[0.12]}\end{array}$ & $\begin{array}{l}0.43 * * * \\
{[0.10]}\end{array}$ & $\begin{array}{l}0.05 \\
{[0.12]}\end{array}$ & $\begin{array}{l}0.89 * * * \\
{[0.24]}\end{array}$ & $\begin{array}{l}0.57 * * * \\
{[0.12]}\end{array}$ & $\begin{array}{l}0.54 * * * \\
{[0.12]}\end{array}$ & $\begin{array}{l}0.02 \\
{[0.14]}\end{array}$ & $\begin{array}{l}1.51 * * * \\
{[0.27]}\end{array}$ & $\begin{array}{l}0.58 * * * \\
{[0.12]}\end{array}$ & $\begin{array}{l}0.70 * * * \\
{[0.13]}\end{array}$ & $\begin{array}{l}-0.09 \\
{[0.13]}\end{array}$ \\
\hline $\begin{array}{l}\text { Adj. R2 } \\
\text { Adj. R2 }\end{array}$ & 0.75 & 0.41 & 0.71 & 0.66 & 0.75 & 0.51 & 0.75 & 0.55 & 0.73 & 0.51 & 0.78 & 0.45 \\
\hline $\begin{array}{l}\text { without GZ } \\
\text { Obs. }\end{array}$ & $\begin{array}{c}\mathbf{0 . 7 0} \\
195\end{array}$ & $\begin{array}{l}\mathbf{0 . 2 1} \\
255\end{array}$ & $\begin{array}{l}\mathbf{0 . 6 4} \\
255\end{array}$ & $\begin{array}{l}\mathbf{0 . 6 4} \\
243\end{array}$ & $\begin{array}{l}\mathbf{0 . 6 8} \\
192\end{array}$ & $\begin{array}{l}\mathbf{0 . 2 3} \\
252\end{array}$ & $\begin{array}{l}\mathbf{0 . 6 2} \\
252\end{array}$ & $\begin{array}{l}\mathbf{0 . 5 5} \\
240\end{array}$ & $\begin{array}{l}\mathbf{0 . 6 1} \\
186\end{array}$ & $\begin{array}{l}\mathbf{0 . 1 7} \\
246\end{array}$ & $\begin{array}{l}\mathbf{0 . 5 5} \\
246\end{array}$ & $\begin{array}{l}\mathbf{0 . 4 5} \\
234\end{array}$ \\
\hline Sample start & 1996M02 & 1991M02 & 1991M02 & 1992M02 & 1996M02 & 1991M02 & 1991M02 & 1992M02 & 1996M02 & 1991M02 & 1991M02 & 1992M02 \\
\hline Sample end & 2012M04 & 2012M04 & 2012M04 & 2012M04 & 2012M01 & 2012M01 & 2012M01 & 2012M01 & 2011M07 & 2011M07 & 2011M07 & 2011M07 \\
\hline
\end{tabular}

Note:

a. Apart from the definition of the dependent variable all results are based on the same specification of the regression equation defined in the notes to Table 2. The transformation of the dependent variable is slightly different: $\nabla^{h} u_{t+h}=\frac{1200}{h+1}\left(u_{t+h}-u_{t-1}\right)$. The unemployment rate is expressed as a fraction. 


\begin{tabular}{|c|c|c|c|c|c|c|c|c|c|c|c|c|c|c|c|}
\hline \multicolumn{16}{|c|}{ Table 4 - Industrial Production: The EMU Period } \\
\hline & \multicolumn{5}{|c|}{ Forecast Horizon $=\mathbf{3}$ months } & \multicolumn{5}{|c|}{ Forecast Horizon $=6$ months } & \multicolumn{5}{|c|}{ Forecast Horizon $=12$ months } \\
\hline & Spain & Italy & Ireland & Portugal & Germany & Spain & Italy & Ireland & Portugal & Germany & Spain & Italy & Ireland & Portugal & Germany \\
\hline Term Spread & $\begin{array}{l}2.52 * * \\
{[1.32]}\end{array}$ & $\begin{array}{l}2.43 \\
{[2.75]}\end{array}$ & $\begin{array}{l}-0.08 \\
{[0.92]}\end{array}$ & $\begin{array}{l}0.75 \\
{[0.60]}\end{array}$ & $\begin{array}{l}0.99 \\
{[1.10]}\end{array}$ & $\begin{array}{l}3.28 * * * \\
{[1.34]}\end{array}$ & $\begin{array}{l}4.55 \\
{[3.20]}\end{array}$ & $\begin{array}{l}-0.30 \\
{[0.77]}\end{array}$ & $\begin{array}{l}0.49 \\
{[0.42]}\end{array}$ & $\begin{array}{l}1.73 \\
{[1.09]}\end{array}$ & $\begin{array}{l}3.91 * * * \\
{[1.41]}\end{array}$ & $\begin{array}{l}7.06 * * \\
{[3.24]}\end{array}$ & $\begin{array}{l}-0.05 \\
{[0.47]}\end{array}$ & $\begin{array}{l}0.33 \\
{[0.35]}\end{array}$ & $\begin{array}{l}2.02 \\
{[0.90]}\end{array}$ \\
\hline Euribor & $\begin{array}{l}-1.25 \\
{[1.03]}\end{array}$ & $\begin{array}{l}-2.72 \\
{[1.77]}\end{array}$ & $\begin{array}{l}0.58 \\
{[1.18]}\end{array}$ & $\begin{array}{l}-1.14 \\
{[1.21]}\end{array}$ & $\begin{array}{l}-4.00 * * \\
{[1.93]}\end{array}$ & $\begin{array}{l}-0.71 \\
{[0.87]}\end{array}$ & $\begin{array}{l}-0.97 \\
{[1.51]}\end{array}$ & $\begin{array}{l}1.14 \\
{[0.81]}\end{array}$ & $\begin{array}{l}-0.85 \\
{[0.72]}\end{array}$ & $\begin{array}{l}-3.33 * * \\
{[1.46]}\end{array}$ & $\begin{array}{l}-0.56 \\
{[0.71]}\end{array}$ & $\begin{array}{l}1.14 \\
{[1.59]}\end{array}$ & $\begin{array}{l}1.89 * * * \\
{[0.36]}\end{array}$ & $\begin{array}{l}-0.47 \\
{[0.56]}\end{array}$ & $\begin{array}{l}-2.79 * * * \\
{[0.72]}\end{array}$ \\
\hline GZ & $\begin{array}{l}5.28 * \\
{[3.18]}\end{array}$ & $\begin{array}{l}-4.51 * * * \\
{[0.58]}\end{array}$ & $\begin{array}{l}-5.25 * * * \\
{[1.90]}\end{array}$ & $\begin{array}{l}5.21 \\
{[3.65]}\end{array}$ & $\begin{array}{l}-10.26 * * * \\
{[4.08]}\end{array}$ & $\begin{array}{l}8.35 * * * \\
{[3.19]}\end{array}$ & $\begin{array}{l}-3.10 * * * \\
{[0.88]}\end{array}$ & $\begin{array}{l}-3.49 * * * \\
{[1.41]}\end{array}$ & $\begin{array}{l}1.89 \\
{[1.76]}\end{array}$ & $\begin{array}{l}-3.49 \\
{[2.93]}\end{array}$ & $\begin{array}{l}7.16^{* *} \\
{[3.21]}\end{array}$ & $\begin{array}{l}-1.87 * * * \\
{[0.59]}\end{array}$ & $\begin{array}{l}-2.86^{* * *} \\
{[0.59]}\end{array}$ & $\begin{array}{l}1.71 \\
{[1.31]}\end{array}$ & $\begin{array}{l}0.62 \\
{[2.22]}\end{array}$ \\
\hline GZ*DUM & $\begin{array}{l}-8.60 * * * \\
{[3.08]}\end{array}$ & $\begin{array}{l}-2.36 * * \\
{[1.05]}\end{array}$ & $\begin{array}{l}0.20 \\
{[1.02]}\end{array}$ & $\begin{array}{l}-10.66^{* *} \\
{[5.35]}\end{array}$ & $\begin{array}{l}-0.96 \\
{[1.74]}\end{array}$ & $\begin{array}{l}-10.77 * * * \\
{[2.98]}\end{array}$ & $\begin{array}{l}-2.31 * * \\
{[1.08]}\end{array}$ & $\begin{array}{l}-0.25 \\
{[0.74]}\end{array}$ & $\begin{array}{l}-6.40 * * * \\
{[2.62]}\end{array}$ & $\begin{array}{l}-2.52 \\
{[2.18]}\end{array}$ & $\begin{array}{l}-9.93 * * * \\
{[2.81]}\end{array}$ & $\begin{array}{l}-3.13 * * * \\
{[1.01]}\end{array}$ & $\begin{array}{l}-0.14 \\
{[0.35]}\end{array}$ & $\begin{array}{l}-5.63 * * * \\
{[1.97]}\end{array}$ & $\begin{array}{l}-3.60 * * \\
{[1.74]}\end{array}$ \\
\hline Inf $^{\text {Home }}$-Inf ${ }^{\text {Ger }}$ & $\begin{array}{l}-5.39 * * * \\
{[2.18]}\end{array}$ & - & - & - & - & $\begin{array}{l}-5.48 * * * \\
{[1.87]}\end{array}$ & - & & - & - & $\begin{array}{l}-2.72 * \\
{[1.45]}\end{array}$ & - & - & - & - \\
\hline$c_{3}+c_{4}=0$ & $\begin{array}{l}-3.31 * * * \\
{[1.06]}\end{array}$ & $\begin{array}{l}-6.87 * * * \\
{[1.87]}\end{array}$ & $\begin{array}{l}-5.05 * * * \\
{[1.20]}\end{array}$ & $\begin{array}{l}-5.45 \\
{[3.81]}\end{array}$ & $\begin{array}{l}-11.22 * * * \\
{[4.48]}\end{array}$ & $\begin{array}{l}-2.42 * * * \\
{[0.90]}\end{array}$ & $\begin{array}{l}-5.41 * * * \\
{[1.41]}\end{array}$ & $\begin{array}{l}-3.74 * * * \\
{[0.89]}\end{array}$ & $\begin{array}{l}-4.51 * * * \\
{[1.87]}\end{array}$ & $\begin{array}{l}-6.01 * * \\
{[2.69]}\end{array}$ & $\begin{array}{l}-2.77 * * * \\
{[1.00]}\end{array}$ & $\begin{array}{l}-5.01 * * * \\
{[1.14]}\end{array}$ & $\begin{array}{l}-3.00 * * * \\
{[0.39]}\end{array}$ & $\begin{array}{l}-3.92 * * * \\
{[1.53]}\end{array}$ & $\begin{array}{l}-2.98 * \\
{[1.65]}\end{array}$ \\
\hline $\begin{array}{l}\text { Adj. R2 } \\
\text { Adj. R2 }\end{array}$ & 0.46 & 0.41 & 0.37 & 0.23 & 0.33 & 0.57 & 0.38 & 0.39 & 0.12 & 0.28 & 0.60 & 0.46 & 0.54 & 0.06 & 0.38 \\
\hline without GZ & 0.27 & 0.17 & 0.24 & 0.18 & 0.09 & 0.27 & 0.16 & 0.24 & 0.12 & 0.11 & 0.21 & 0.13 & 0.20 & 0.05 & 0.18 \\
\hline Obs. & 160 & 160 & 160 & 156 & 160 & 157 & 157 & 157 & 153 & 157 & 151 & 151 & 151 & 147 & 151 \\
\hline Sample start & 1999M01 & 1999M01 & 1999M01 & 1999M05 & 1999M01 & 1999M01 & 1999M01 & 1999M01 & 1999M05 & 1999M01 & 1999M01 & 1999M01 & 1999M01 & 1999M05 & 1999M01 \\
\hline Sample end & 2012M04 & 2012M04 & 2012M04 & 2012M04 & 2012M04 & 2012M01 & 2012M01 & 2012M01 & 2012M01 & 2012M01 & 2011M07 & 2011M07 & 2011M07 & 2011M07 & 2011M07 \\
\hline
\end{tabular}

Notes: See notes to Table 1.

a. For Portugal the GZ variable has been differenced to make it stationary. 


\begin{tabular}{|c|c|c|c|c|c|c|c|c|c|c|c|c|c|c|c|}
\hline \multicolumn{16}{|c|}{ Table 5 - Unemployment: The EMU Period } \\
\hline & \multicolumn{5}{|c|}{ Forecast Horizon $=3$ months } & \multicolumn{5}{|c|}{ Forecast Horizon $=6$ months } & \multicolumn{5}{|c|}{ Forecast Horizon $=12$ months } \\
\hline & Spain & Italy & Ireland & Portugal & Germany & Spain & Italy & Ireland & Portugal & Germany & Spain & Italy & Ireland & Portugal & Germany \\
\hline Term Spread & $\begin{array}{l}-0.58 * * * \\
{[0.23]}\end{array}$ & $\begin{array}{l}0.09 \\
{[0.14]}\end{array}$ & $\begin{array}{l}-0.03 \\
{[0.05]}\end{array}$ & $\begin{array}{l}-0.20 * * \\
{[0.09]}\end{array}$ & $\begin{array}{l}0.05 \\
{[0.08]}\end{array}$ & $\begin{array}{l}-1.27 * * * \\
{[0.38]}\end{array}$ & $\begin{array}{l}0.10 \\
{[0.12]}\end{array}$ & $\begin{array}{l}-0.19 * \\
{[0.11]}\end{array}$ & $\begin{array}{l}-0.22 * * * \\
{[0.84]}\end{array}$ & $\begin{array}{l}0.01 \\
{[0.10]}\end{array}$ & $\begin{array}{l}-1.67 * * * \\
{[0.32]}\end{array}$ & $\begin{array}{l}-0.21 \\
{[0.17]}\end{array}$ & $\begin{array}{l}-0.07 \\
{[0.12]}\end{array}$ & $\begin{array}{l}-0.28 * * * \\
{[0.05]}\end{array}$ & $\begin{array}{l}0.07 \\
{[0.16]}\end{array}$ \\
\hline Euribor & $\begin{array}{l}0.22 \\
{[0.25]}\end{array}$ & $\begin{array}{l}0.03 \\
{[0.13]}\end{array}$ & $\begin{array}{l}0.02 \\
{[0.02]}\end{array}$ & $\begin{array}{l}0.09 \\
{[0.14]}\end{array}$ & $\begin{array}{l}0.09 \\
{[0.10]}\end{array}$ & $\begin{array}{l}-0.16 \\
{[0.18]}\end{array}$ & $\begin{array}{l}-0.00 \\
{[0.12]}\end{array}$ & $\begin{array}{l}0.02 \\
{[0.17]}\end{array}$ & $\begin{array}{l}0.06 \\
{[0.13]}\end{array}$ & $\begin{array}{l}0.14 \\
{[0.13]}\end{array}$ & $\begin{array}{l}-0.16 \\
{[0.18]}\end{array}$ & $\begin{array}{l}-0.23 \\
{[0.17]}\end{array}$ & $\begin{array}{l}0.01 \\
{[0.18]}\end{array}$ & $\begin{array}{l}-0.02 \\
{[0.09]}\end{array}$ & $\begin{array}{l}0.29 * * \\
{[0.14]}\end{array}$ \\
\hline GZ & $\begin{array}{l}-1.05 * \\
{[0.55]}\end{array}$ & $\begin{array}{l}0.28 * * * \\
{[0.10]}\end{array}$ & $\begin{array}{l}0.17 * * \\
{[0.07]}\end{array}$ & $\begin{array}{l}0.43 \\
{[0.44]}\end{array}$ & $\begin{array}{l}0.38^{*} \\
{[0.23]}\end{array}$ & $\begin{array}{l}-0.81 \\
{[0.56}\end{array}$ & $\begin{array}{l}0.22 * * \\
{[0.10]}\end{array}$ & $\begin{array}{l}0.19 * \\
{[0.11]}\end{array}$ & $\begin{array}{l}0.48 \\
{[0.39]}\end{array}$ & $\begin{array}{l}0.15 \\
{[0.26]}\end{array}$ & $\begin{array}{l}-1.08 \\
{[0.67]}\end{array}$ & $\begin{array}{l}0.12 \\
{[0.11]}\end{array}$ & $\begin{array}{l}0.29 * * * \\
{[0.10]}\end{array}$ & $\begin{array}{l}0.10 \\
{[0.32]}\end{array}$ & $\begin{array}{l}-0.35 \\
{[0.28]}\end{array}$ \\
\hline GZ*DUM & $\begin{array}{l}1.69 * * * \\
{[0.58]}\end{array}$ & $\begin{array}{l}0.45^{* * * *} \\
{[0.11]}\end{array}$ & $\begin{array}{l}0.26^{* * * *} \\
{[0.07]}\end{array}$ & $\begin{array}{l}0.59 \\
{[0.49]}\end{array}$ & $\begin{array}{l}-0.13 \\
{[0.15]}\end{array}$ & $\begin{array}{l}1.38^{* * * *} \\
{[0.42]}\end{array}$ & $\begin{array}{l}0.49 * * * \\
{[0.11]}\end{array}$ & $\begin{array}{l}0.38 * * * \\
{[0.10]}\end{array}$ & $\begin{array}{l}0.45 \\
{[0.43]}\end{array}$ & $\begin{array}{l}-0.02 \\
{[0.19]}\end{array}$ & $\begin{array}{l}2.10^{* * * *} \\
{[0.54]}\end{array}$ & $\begin{array}{l}0.65^{* * *} \\
{[0.13]}\end{array}$ & $\begin{array}{l}0.45 * * * \\
{[0.11]}\end{array}$ & $\begin{array}{l}0.36 \\
{[0.42]}\end{array}$ & $\begin{array}{l}0.15 \\
{[0.21]}\end{array}$ \\
\hline $\operatorname{Inf}^{\text {Home }}-$ Inf $^{\text {Ger }}$ & - & $\begin{array}{l}-0.34^{* *} \\
{[0.15]}\end{array}$ & $\begin{array}{l}0.31 * * * \\
{[0.08]}\end{array}$ & - & - & - & $\begin{array}{l}-0.36^{* * * *} \\
{[0.12]}\end{array}$ & $\begin{array}{l}0.44 * * * \\
{[0.16]}\end{array}$ & - & - & - & $\begin{array}{l}-0.28^{*} \\
{[0.16]}\end{array}$ & $\begin{array}{l}0.45^{* * *} \\
{[0.16]}\end{array}$ & - & - \\
\hline$c_{3}+c_{4}=0$ & $\begin{array}{l}0.64 * * * \\
{[0.26]}\end{array}$ & $\begin{array}{l}0.73 * * * \\
{[0.10]}\end{array}$ & $\begin{array}{l}0.43 * * * \\
{[0.10]}\end{array}$ & $\begin{array}{l}1.02 * * * \\
{[0.36]}\end{array}$ & $\begin{array}{l}0.24 \\
{[0.20]}\end{array}$ & $\begin{array}{l}0.57 * * \\
{[0.29]}\end{array}$ & $\begin{array}{l}0.71 * * * \\
{[0.09]}\end{array}$ & $\begin{array}{l}0.57 * * * \\
{[0.13]}\end{array}$ & $\begin{array}{l}0.93 * * * \\
{[0.29]}\end{array}$ & $\begin{array}{l}0.13 \\
{[0,22]}\end{array}$ & $\begin{array}{l}1.01 * * * \\
{[0.28]}\end{array}$ & $\begin{array}{l}0.77 * * * \\
{[0.10]}\end{array}$ & $\begin{array}{l}0.74 * * * \\
{[0.14]}\end{array}$ & $\begin{array}{l}0.46 \\
{[0.35]}\end{array}$ & $\begin{array}{l}-0.20 \\
{[0.21]}\end{array}$ \\
\hline $\begin{array}{l}\text { Adj. R2 } \\
\text { Adj. R2 }\end{array}$ & 0.74 & 0.62 & 0.71 & 0.33 & 0.58 & 0.74 & 0.69 & 0.70 & 0.34 & 0.46 & 0.77 & 0.66 & 0.76 & 0.28 & 0.35 \\
\hline $\begin{array}{l}\text { without GZ } \\
\text { Obs. }\end{array}$ & $\begin{array}{c}\mathbf{0 . 6 8} \\
160\end{array}$ & $\begin{array}{l}\mathbf{0 . 3 3} \\
160\end{array}$ & $\begin{array}{l}\mathbf{0 . 5 4} \\
160\end{array}$ & $\begin{array}{l}\mathbf{0 . 2 4} \\
156\end{array}$ & $\begin{array}{l}\mathbf{0 . 5 7} \\
160\end{array}$ & $\begin{array}{l}\mathbf{0 . 6 7} \\
157\end{array}$ & $\begin{array}{l}\mathbf{0 . 3 7} \\
157\end{array}$ & $\begin{array}{l}\mathbf{0 . 5 1} \\
157\end{array}$ & $\begin{array}{l}\mathbf{0 . 2 3} \\
153\end{array}$ & $\begin{array}{l}\mathbf{0 . 4 6} \\
157\end{array}$ & $\begin{array}{l}\mathbf{0 . 6 1} \\
151\end{array}$ & $\begin{array}{l}\mathbf{0 . 1 5} \\
151\end{array}$ & $\begin{array}{l}\mathbf{0 . 4 0} \\
151\end{array}$ & $\begin{array}{l}\mathbf{0 . 1 1} \\
147\end{array}$ & $\begin{array}{l}\mathbf{0 . 3 4} \\
151\end{array}$ \\
\hline Sample start & 1999M01 & 1999M01 & 1999M01 & 1999M05 & 1999M01 & 1999M01 & 1999M01 & 1999M01 & 1999M05 & 1999M01 & 1999M01 & 1999M01 & 1999M01 & 1999M05 & 1999M01 \\
\hline Sample end & 2012M04 & 2012M04 & 2012M04 & 2012M04 & 2012M04 & 2012M01 & 2012M01 & 2012M01 & 2012M01 & 2012M01 & 2011M07 & 2011M07 & 2011M07 & 2011M07 & 2011M07 \\
\hline
\end{tabular}


Table 6-Quarterly GDP

\begin{tabular}{|c|c|c|c|c|c|c|c|c|c|c|c|c|}
\hline & \multicolumn{4}{|c|}{ Horizon $=1$ quarter } & \multicolumn{4}{|c|}{ Horizon $=2$ quarters } & \multicolumn{4}{|c|}{ Horizon $=4$ quarters } \\
\hline & Spain & Italy & Ireland & Germany & Spain & Italy & Ireland & Germany & Spain & Italy & Ireland & Germany \\
\hline \multirow[t]{2}{*}{ Term } & 0.22 & $1.10^{* *}$ & -0.68 & -0.02 & 0.31 & $1.29 *$ & -0.16 & 0.17 & $0.75 * *$ & $1.43 * *$ & 0.26 & 0.20 \\
\hline & {$[0.25]$} & {$[0.57]$} & {$[0.62]$} & [0.39] & {$[0.28]$} & [0.69] & {$[0.52]$} & {$[0.35]$} & {$[0.35]$} & {$[0.67]$} & {$[0.24]$} & {$[0.35]$} \\
\hline \multirow[t]{2}{*}{ Euribor } & -0.26 & 0.26 & -0.24 & $-0.91 *$ & -0.24 & 0.32 & -0.05 & $-0.74 * *$ & -0.14 & $0.39 *$ & 0.46 & $-0.59 * *$ \\
\hline & {$[0.18]$} & {$[0.20]$} & [0.39] & {$[0.5]$} & {$[0.20]$} & {$[0.22]$} & {$[0.34]$} & {$[0.37]$} & {$[0.22]$} & {$[0.22]$} & {$[0.35]$} & {$[0.28]$} \\
\hline \multirow[t]{2}{*}{ GZ } & 0.61 & $-0.48 * *$ & $-1.52 * * *$ & -0.20 & 0.73 & $-0.41 *$ & $-0.92 *$ & 0.13 & 0.86 & $-0.37 * *$ & $-0.94 * * *$ & 0.36 \\
\hline & {$[0.45]$} & {$[0.16]$} & {$[0.61]$} & {$[0.59]$} & {$[0.55]$} & {$[0.21]$} & {$[0.48]$} & {$[0.41]$} & {$[0.62]$} & {$[0.17]$} & {$[0.34]$} & {$[0.27]$} \\
\hline \multirow[t]{2}{*}{ GZ*DUM } & $-1.71 * * *$ & $-1.13 * * *$ & $-0.81 * *$ & -1.09 & $-2.00 * * *$ & $-1.15^{* * *}$ & $-1.04 * * *$ & -1.01 & $2.54 * * *$ & $-1.42 * * *$ & $-1.03 * * *$ & $-0.95^{*}$ \\
\hline & {$[0.48]$} & {$[0.42]$} & {$[0.38]$} & {$[0.76]$} & {$[0.58]$} & {$[0.35]$} & {$[0.30]$} & {$[0.66]$} & {$[0.62]$} & {$[0.33]$} & {$[0.24]$} & {$[0.53]$} \\
\hline \multirow[t]{2}{*}{$\operatorname{Inf}^{\text {Home }}-$ Inf ${ }^{\text {Ger }}$} & $-0.71 *$ & - & $-0.97 *$ & - & $-0.75^{*}$ & - & $-0.91 * *$ & - & - & - & $-0.71 * * *$ & - \\
\hline & {$[0.39]$} & & {$[0.56]$} & & {$[0.46]$} & & {$[0.40]$} & & & & {$[0.26]$} & \\
\hline$c_{3}+c_{4}=0$ & $\begin{array}{l}-1.10 * * * \\
{[0.22]}\end{array}$ & $\begin{array}{l}-1.61 * * * \\
{[0.48]}\end{array}$ & $\begin{array}{l}-2.33 * * * \\
{[0.40]}\end{array}$ & $\begin{array}{l}-1.29 \\
{[1.00]}\end{array}$ & $\begin{array}{l}-1.27 * * * \\
{[0.24]}\end{array}$ & $\begin{array}{l}-1.56^{* * * *} \\
{[0.40]}\end{array}$ & $\begin{array}{l}-1.96 * * * \\
{[0.32]}\end{array}$ & $\begin{array}{l}-0.89 \\
{[0.73]}\end{array}$ & $\begin{array}{l}-1.85 * * * \\
{[0.39]}\end{array}$ & $\begin{array}{l}-1.79 * * * \\
{[0.35]}\end{array}$ & $\begin{array}{l}-1.97 * * * \\
{[0.21]}\end{array}$ & $\begin{array}{l}-0.59 \\
{[0.52]}\end{array}$ \\
\hline \multirow{2}{*}{$\begin{array}{l}\text { Adj. R2 } \\
\text { Adj. R2 } \\
\text { without GZ }\end{array}$} & 0.85 & 0.53 & 0.52 & 0.20 & 0.85 & 0.53 & 0.63 & 0.20 & 0.84 & 0.50 & 0.84 & 0.21 \\
\hline & 0.73 & 0.22 & 0.24 & 0.08 & 0.68 & 0.20 & 0.33 & 0.09 & 0.59 & 0.06 & 0.43 & 0.09 \\
\hline Obs & 64 & 80 & 56 & 80 & 63 & 79 & 55 & 79 & 61 & 77 & 53 & 77 \\
\hline Sample Start & 1996Q2 & 1992Q2 & 1998Q2 & 1992Q2 & 1996Q2 & 1992Q2 & 1998Q2 & 1992Q2 & 1996Q2 & 1992Q2 & 1998Q2 & 1992Q2 \\
\hline Sample End & 2012Q1 & 2012Q1 & 2012Q1 & 2012Q1 & 2011Q4 & 2011Q4 & 2011Q4 & 2011Q4 & 2011Q2 & 2011Q2 & 2011Q2 & 2011Q2 \\
\hline
\end{tabular}

Notes: a. All estimated regressions are based on quarterly data and include 4 lags of the log difference of real GDP $\left(\nabla y_{t}\right)$ :

$$
\begin{aligned}
\nabla^{h} y_{t+h} & =b_{0}+\sum_{i=1}^{4} b_{i} \nabla y_{t-i}+c_{1} T S_{t}+c_{2} E U_{t}+c_{3} G Z_{t}+c_{4} G Z_{t} * D U M_{t}+c_{5}\left(I N F_{t}^{\text {Home }}-I N F_{t}^{G e r}\right)+\epsilon_{t+h} \\
& \text { where } \nabla^{h} y_{t+h}=\frac{c}{h+1} \ln \left(\frac{Y_{t+h}}{Y_{t-1}}\right) \quad h=1,2,4 \text { (forecast horizon) } \quad c=400 \text { (scaling constant for quarterly data) }
\end{aligned}
$$


Table 7 - Quarterly GDP: The EMU Period

\begin{tabular}{|c|c|c|c|c|c|c|c|c|c|c|c|c|}
\hline \multirow{4}{*}{ Term } & \multicolumn{4}{|c|}{ Horizon $=1$ quarter } & \multicolumn{4}{|c|}{ Horizon $=2$ quarters } & \multicolumn{4}{|c|}{ Horizon $=4$ quarters } \\
\hline & Spain & Italy & Portugal & Germany & Spain & Italy & Portugal & Germany & Spain & Italy & Portugal & Germany \\
\hline & 0.30 & 0.86 & -0.18 & -0.48 & 0.36 & 1.61 & -0.07 & 0.18 & $0.76^{* *}$ & $2.38 * *$ & 0.08 & 0.41 \\
\hline & {$[0.32]$} & {$[0.80]$} & {$[0.20]$} & {$[0.90]$} & {$[0.35]$} & [1.12] & {$[0.15]$} & [1.13] & {$[0.38]$} & {$[1.12]$} & {$[0.55]$} & {$[1.13]$} \\
\hline \multirow[t]{2}{*}{ Euribor } & -0.05 & -0.67 & 0.13 & -0.96 & 0.03 & -0.14 & 0.07 & -0.64 & 0.03 & 0.48 & 0.12 & -0.55 \\
\hline & {$[0.18]$} & {$[0.45]$} & {$[0.40]$} & {$[0.63]$} & {$[0.20]$} & {$[0.44]$} & {$[0.38]$} & {$[0.48]$} & {$[0.19]$} & {$[0.62]$} & {$[0.29]$} & {$[0.46]$} \\
\hline \multirow[t]{2}{*}{ GZ } & 0.35 & $-1.68 * * *$ & -1.43 & $-3.59 * *$ & 0.69 & $-1.26 * * *$ & -0.59 & -2.03 & 0.90 & $-0.91 * * *$ & -0.01 & -0.11 \\
\hline & {$[0.63]$} & {$[0.41]$} & {$[1.95]$} & {$[1.70]$} & {$[0.75]$} & {$[0.26]$} & {$[1.25]$} & [1.37] & {$[0.79]$} & {$[0.30]$} & {$[1.30]$} & {$[1.32]$} \\
\hline \multirow[t]{2}{*}{ GZ*DUM } & $-1.33 * * *$ & $-0.90 * * *$ & -0.92 & 0.25 & $-1.81 * * *$ & $-0.89 * * *$ & -1.44 & -0.16 & $-2.54 * * *$ & $-1.22 * * *$ & $-2.76^{*}$ & -0.75 \\
\hline & {$[0.49]$} & {$[0.25]$} & [2.33] & {$[0.56]$} & {$[0.60]$} & {$[0.22]$} & {$[1.60]$} & {$[0.75]$} & {$[0.71]$} & {$[0.26]$} & {$[1.60]$} & {$[0.78]$} \\
\hline$c_{3}+c_{4}=0$ & $\begin{array}{l}-0.98 * * * \\
{[0.31]}\end{array}$ & $\begin{array}{l}-2.58 * * * \\
{[0.62]}\end{array}$ & $\begin{array}{l}-2.35^{* *} \\
{[1.05]}\end{array}$ & $\begin{array}{c}-3.34 * * \\
{[1.67]}\end{array}$ & $\begin{array}{l}-1.12 * * * \\
{[0.34]}\end{array}$ & $\begin{array}{l}-2.15 * * * \\
{[0.37]}\end{array}$ & $\begin{array}{c}-2.03 * * * \\
{[0.76]}\end{array}$ & $\begin{array}{l}-2.19^{* *} \\
{[1.16]}\end{array}$ & $\begin{array}{l}-1.63 * * * \\
{[0.33]}\end{array}$ & $\begin{array}{l}-2.13 * * * \\
{[0.33]}\end{array}$ & $\begin{array}{l}-2.3 * * * \\
{[0.55]}\end{array}$ & $\begin{array}{l}-0.86 \\
{[0.89]}\end{array}$ \\
\hline \multirow{2}{*}{$\begin{array}{l}\text { Adj R2 } \\
\text { Adj. R2 } \\
\text { without GZ }\end{array}$} & 0.83 & 0.68 & 0.21 & 0.33 & 0.82 & 0.64 & 0.22 & 0.22 & 0.83 & 0.63 & 0.15 & 0.15 \\
\hline & 0.71 & 0.25 & 0.04 & 0.09 & 0.66 & 0.27 & 0.08 & 0.08 & 0.54 & 0.14 & -0.09 & 0.06 \\
\hline Obs & 53 & 53 & 51 & 53 & 52 & 52 & 50 & 52 & 50 & 50 & 48 & 50 \\
\hline Sample Start & 1999Q1 & 1999Q1 & 1999Q3 & 1999Q1 & 1999Q1 & 1999Q1 & 1999Q3 & 1999Q1 & 1999Q1 & 1999Q1 & 1999Q3 & 1999Q1 \\
\hline Sample End & 2012Q1 & 2012Q1 & 2012Q1 & 2012Q1 & 2011Q4 & 2011Q4 & 2011Q4 & 2011Q4 & 2011Q2 & 2011Q2 & 2011Q2 & 2011Q2 \\
\hline
\end{tabular}


Appendix:

Table A1: Yields (\%) on 10-yr Government Bonds

\begin{tabular}{|l|l|l|l|l|l|}
\hline Date & Germany & Italy & Spain & Portugal & Ireland \\
\hline February 2013 & 1.54 & 4.49 & 5.22 & 6.40 & 3.78 \\
\hline April 2012 & 1.83 & 5.68 & 5.79 & 12.01 & 6.88 \\
\hline July 2007 & 4.50 & 4.76 & 4.60 & 4.73 & 4.59 \\
\hline January 1999 & 3.70 & 3.92 & 3.88 & 3.90 & 3.89 \\
\hline January 1993 & 7.15 & 13.43 & 12.16 & 10.67 (July) & 9.88 \\
\hline
\end{tabular}


Table A2: Data Description and Sources

\begin{tabular}{|c|c|c|c|c|c|c|}
\hline Variable & Code & Description & Raw units & Frequency & Transformation & Source \\
\hline Industrial Production & IP or $\mathrm{Y}$ & $\begin{array}{l}\text { Total industrial production index. Seasonally } \\
\text { and working day adjusted. }\end{array}$ & $\begin{array}{l}\text { Index }(\text { base year }= \\
2005)\end{array}$ & Monthly & $\begin{array}{l}\text { The log difference over } \\
\text { one period or log- } \\
\text { difference over h-periods. }\end{array}$ & OECD \\
\hline GDP & GDP or $\mathrm{Y}$ & $\begin{array}{l}\text { This is real GDP. Seasonally and working day } \\
\text { adjusted }\end{array}$ & $\begin{array}{l}\text { Millions of Euro } \\
(2000 \text { market } \\
\text { prices })\end{array}$ & Quarterly & $\begin{array}{l}\text { The log difference over } \\
\text { one period or log- } \\
\text { difference over h-periods } \\
\text { when used as dependant } \\
\text { variable (see equation (1)) }\end{array}$ & EuroStat \\
\hline Unemployment & $\mathrm{U}$ & $\begin{array}{l}\text { Total Unemployment rate. Seasonally } \\
\text { adjusted. }\end{array}$ & Percentage points & Monthly & None & OECD \\
\hline GZ spread & GZ & $\begin{array}{l}\text { Spread is constructed from yields on bond } \\
\text { securities and risk-free rate (below). The } \\
\text { yield to redemption on each bond is } \\
\text { calculated by DataStream. }\end{array}$ & Percentage points & Monthly & None & $\begin{array}{l}\text { DataStream and own } \\
\text { calculations }\end{array}$ \\
\hline Risk-free rate & $\mathrm{r}^{\mathrm{f}}$ & $\begin{array}{l}\text { We construct a German government yield } \\
\text { curve from zero rates provided by the } \\
\text { German Bundesbank and interpolate. See text } \\
\text { for more details. }\end{array}$ & Percentage points & Monthly & $\begin{array}{l}\text { Not-transformed. Used to } \\
\text { calculate the GZ spread }\end{array}$ & German Bundesbank \\
\hline Inflation & CPI & CPI all products. Not seasonally adjusted. & Index & Monthly & $\begin{array}{l}\text { Transformed into log- } \\
\text { difference over one year. }\end{array}$ & DataStream \\
\hline $\begin{array}{l}\text { Short term rate } \\
\text { (nominal) }\end{array}$ & EU & $\begin{array}{l}\text { Short term rate provided by the OECD. It } \\
\text { consists of different rates over time. It is the } \\
\text { Euribor interbank rate after } 2000 \text {. Prior to } \\
\text { that it is the shortest maturity government } \\
\text { bond yield. }\end{array}$ & Percentage points & Monthly & None & OECD \\
\hline Term spread & TS & $\begin{array}{l}\text { Difference between long and short end of } \\
\text { DataStream-calculated yield curve. }\end{array}$ & Percentage points & Monthly & None & $\begin{array}{l}\text { DataStream and own } \\
\text { calculations }\end{array}$ \\
\hline
\end{tabular}

